ECPS Leader Profile Series 근?

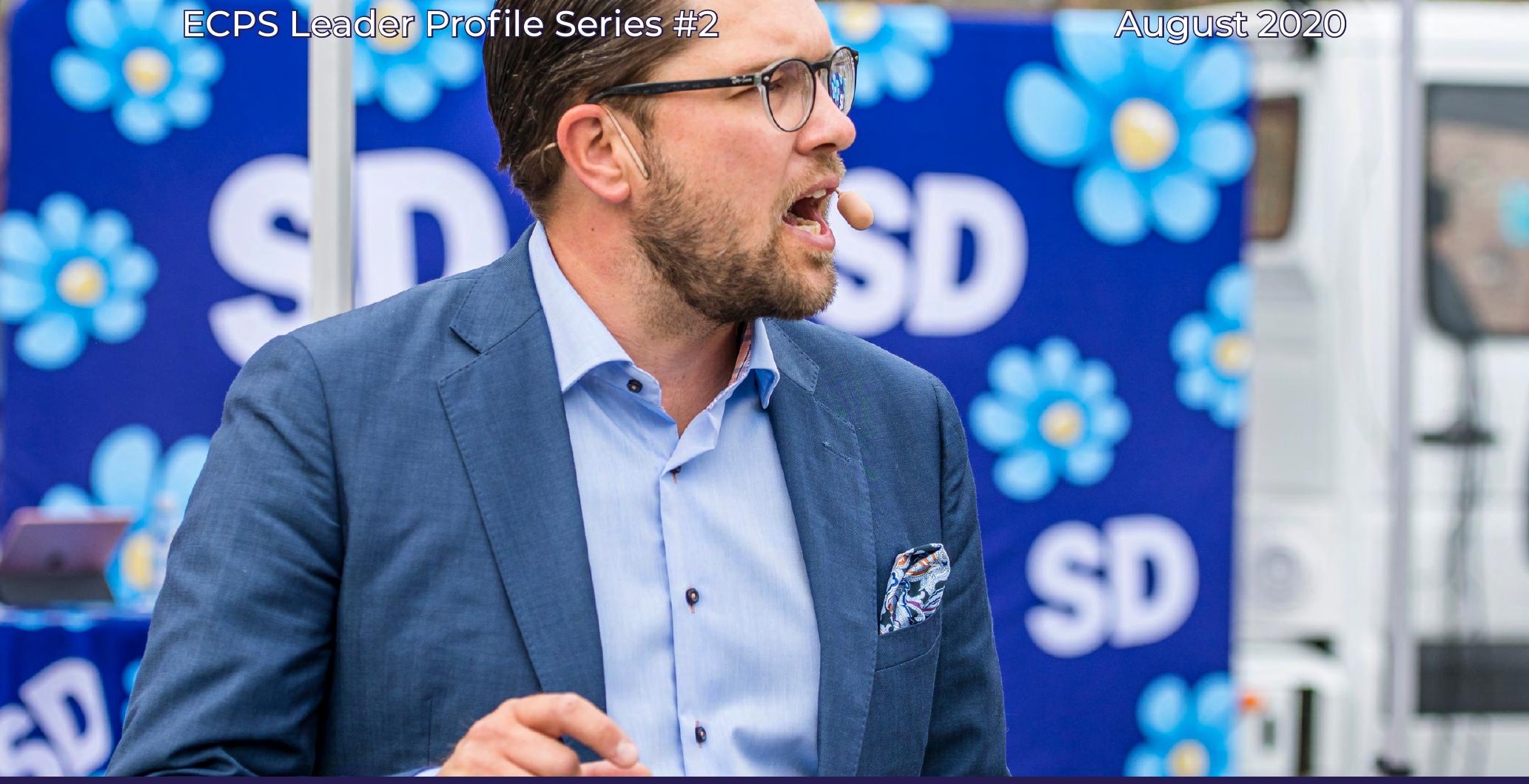

AUTHOR: Bulent Kenes

\title{
Per Jimmie Åkesson: A Smiling Wolf in Sheep's Clothing?
}

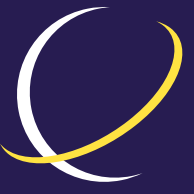




\section{Per Jimmie Åkesson: A Smiling Wolf in Sheep's Clothing?}

BY BULENT KENES

\section{ABSTRACT}

Jimmie Åkesson and his party, the Sweden Democrats (SD), are not yet authentically democratic. They are still "the same old iron gang as usual" despite concerted efforts to change their image. Of course, Åkesson has steered the SD away from the Nazi movement onto a more parliamentary path. But its essence - alarmist resistance to immigrants and Islamophobia - has remained the same, and there is still no solid indication that Åkesson has matured or moderated over the years.

BULENT KENES is an academic and a journalist who has over 25 years of professional experience. He has managed multiple publications, both in Turkish and English.

ECPS Leader Profile Series offer analyses of political leaders and prominent public figures with populist tendencies. Unless otherwise indicated, the views expressed by the author are only attributable him and not to any institution with which they are associated.

The profile available for free downloading from the ECPS website (www. populismstudies.org)

(C)ECPS 2021 


\section{Table of contents}

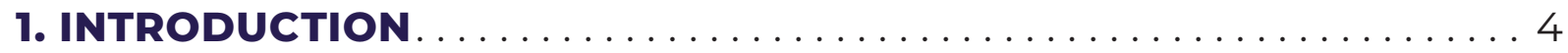

2. A STRONG LEADER WITHOUT MUCH CHARISMA .......... 9

3. RACISM: HOW SUCCESSFUL HAS THE SD BEEN IN CHANGING ITS SKIN?

4. IMMIGRATION \& MULTICULTURALISM: "SWEDEN BELONGS TO THE SWEDES" 


\section{INTRODUCTION}

Per Jimmie Åkesson is a Swedish author and leader of the populist radical right (PRR) Sweden Democrats (SD) party. Åkesson's path to politics was both normal and unusual: he began his political activism through the anti-abortion movement and Scientology meetings (Poohl, 2011). Åkesson, who was also politically active as a member of Moderates (M) for a short period of time, first became a member of Sölvesborg City Council in 1998, running on the SD platform. After he became president of the party in 2005, he took the SD from the political margin to the center, making it into one of Sweden's largest parties (Expo, 2018). He has been a member of the Riksdag (Swedish Parliament) representing Jönköping County since 2010 (Parliament, 2010).

Åkesson was born in 1979 in Ivetofta in Skåne County (Lindström, 2010), but grew up in Sölvesborg in Blekinge County. He had tried to get in touch with the local department of the neo-nazi New Democracy party, but his efforts were unsuccessful (Poohl, 2011). Instead, he became a member of the Moderate Youth League, the youth wing of the Moderate Party. But he soon left the Moderates and contacted the SD in December 1994. On New Year's Eve 1994, he and some of his comrades founded the the Sweden Democratic Youth (SDU: The youth wing of the SD) in Sölvesborg (Expo, 2018).

Despite his involvement in 1994, he claimed that he did not join the party until Mikael Jansson was elected as party leader in March 1995, when the party began a process of renewal (Expo, 2018). Therefore, the question of exactly when Åkesson joined the SD is still shrouded in obscurity.

Although the specifics are still debated, he joined the party sometime between 1994 and 1995. Under normal circumstances, a few months may seem an insignificant detail. But in Åkesson's case, it matters. In the chapter of SD's anniversary book (20 röster om 20 år) about him, Åkesson makes an allegation that he did not join the SD until controversial party leader Anders Klarström left his post in favor of Mikael Jansson. For Åkesson, the change of party leadership represents a breaking point in the SD's history. Mikael Jansson symbolized the "new." The new SD started the process of purging racists and neo-Nazis. For Åkesson, it is important to stand on the right side of the line.

The problem is that his story is not right. His narrative - of joining in 1995 is contradicted by a text Åkesson wrote for SDU-Syd's member magazine in 1997: "We first had contact with the SD sometime in December of the same year (1994). During a meeting on New Year's Eve, we decided to start working party politics, and that a local SDU department would eventually be formed" (Åkesson, 1997). And in a 1999 interview with The Democrat, he said that he joined the SD's youth association "after the 1994 elections" (Poohl, 2011). In 2012, Lars Adaktusson claimed in the Metro newsapaper that Åkesson joined 
the SD "when the party politics were still shaped by right-wing nationalists and skinheads,"(Mattsson, 2015). However, the SD's press secretary Christian Krappedal has accepted Åkesson's official narrative and stated that he became a party member in the spring of 1995 (Nyman, 2015).

It is also difficult to find out how exactly Åkesson came into contact with the SD. He himself says that it was one of his teachers' negative attitudes about the SD that attracted him to the party: "The teacher said it was a bad party and it was awful to vote for it. Anyway, there were two students in the class who had voted for the SD and then it led to a great discussion. Then I became a little curious and looked more closely at the party. There was a lot I could do there" (Poohl, 2011). But in 20 röster om 20 år, Åkesson told a different story. There, Åkesson described distancing himself from Sölvesborg's fashionable youth circles; then, together with some friends, he began to search the "outfields." There he found the Sweden Democrats. The correct explanation remains unclear. In any case, Åkesson's political search ended with the SD (Poohl, 2011).

Akkesson claims in his book Satis Politio that his main political ambition was to "distance the party from questionable ideas" (Åkesson, 2013). Paradoxically, he also claims that he has not seen any form of racism in the SD - this despite working with Tina Hallgren-Bengtsson, an SD member Höör, while founding the SDU in Sölvesborg; in 1996, Hallgreen-Bengtsoon burned books in bonfire while wearing a Nazi uniform (Expo, 2018). Moreover, many who have criticized the SD pointed out that party members have expressed Nazi views. In some cases, they've used Nazi symbols and uniforms. Both of the then-SD leader and the youth union chairman were Nazis. SD members dressed in Nazi uniforms - even at the party's official meetings. For instance, Kenneth Sandberg, who later left the SD and appeared in Nazi contexts including as a writer for a Nazi newspaper - sat with Åkesson on the party board (Mattsson, 2015). In the SD's newspaper Kurier, the aforementioned Hallgren-Bengtsson was widely advertised as deputy party leader. After she resigned from the party, she and her husband Jan Bengtsson went over to the more radical National Socialist Front.

There are many similar examples, i.e. many people in the ranks of the SD have previously expressed sympathies with racist or national socialist ideas (Mattsson, 2015). Ákesson states in Satis Politio that he joined the SD with the intention of fundamentally changing the party, but wrote that, "Not even Mikael Jansson succeeded fully in the clean-up during his ten years at the helm." Åkesson didn't deny that the former party leader (Klarström) was a Nazi, nor that the party has links to Nazism and skinhead culture, but he claims that such links are exaggerated (Åkesson, 2013).

Åkesson studied a three-year social science program between 1995-1998 at the Furulund School in Sölvesborg (Adolfsson, 2013). In 1997, he was elected as a deputy member of the party board (jimmieåkesson.se). Then, he began his studies at Lund University in 1999. During his first year, he studied philos- 
ophy and research policy. He then studied political science, law, economic history, economics and social geography. According to his autobiography Satis Polito, he was most attracted to the SD's policies opposing the European Union (EU) and immigration: "Like so many others, I stuck to the SD's immigration policy, but it was probably above all the party's view of the EU that made me to take the final decision" (Åkesson, 2013 \& jimmieåkesson.se).

Prior to working for the party full-time, Åkesson worked as a web designer at the company BMJ Aktiv, which he co-founded with Björn Söder, the former SD party secretary. Meanwhile, the local SDU association quickly became one of the largest and most active political youth associations in the municipality. This laid the foundation for the municipal elections in 1998, when Åkesson was elected to public office as a councilman in Sölvesborg. The same year, he also became deputy chairman of the SDU (Lindström, 2010).

Åkesson recounted his political experiences in those days with the following words: "Of course, as a 19-year-old and a Swedish Democrat, it was great and exciting to take a seat in an assembly elected by the people, especially since it was about something you yourself have been involved in building from the ground up. At the same time, it would have been good to have someone more experienced to learn from, and I must say that I envy the youth politicians in the established parties because they have that advantage. As a Swedish Democrat, so far, we have had to start from scratch, which has been useful but extremely challenging" (jimmieåkesson.se).

His role within the SD national organization began in 1997, when he was elected alternate member of the party board. Since then, he has held many different assignments, including being chairman of the SDU between 20002005 , within the party's communications unit where he was involved in advertising production and press contacts. He wrote press releases and produced information materials and political programs. Åkesson was also assigned to the chair of the party's program commission. He was the lead author of the principle program adopted in 2003 and of the "democracy program" that was produced in the fall of 2004. In addition, he put together the election manifesto of 2002. He described those days: "Politically, the ideology and democracy issues interest me above all. The development of recent decades in Sweden is interesting to study, especially in relation to other countries. There is no doubt that Swedish society has [been] derailed in many respects" (jimmieåkesson.se).

In the years before he became the party chairman, Åkesson devoted a great deal of his time and efforts to organizational and election planning work. He was a driving force in the SD's central election planning group. Before the 2004 European Parliament (EP) election, he was one of the party's top names behind Sten Andersson and made himself known as a diligent speaker. The party tripled its support in the European Parliament (jimmieåkesson.se). 


\section{7}

Åkesson received massive attention and reaction when he published a debate article in Aftonbladet on October 19, 2009 that was critical of Islam. The article argued that various phenomena associated with Islam were the "greatest foreign threat to Sweden since World War II" and it highlighted Muslims as Sweden's biggest foreign threat.

After some internal disputes within the party, Åkesson was proposed by the nomination committee to be the new SD leader in 2005. At the party congress on May 7, 2005, Åkesson won a vote over former party leader Mikael Jansson (Widfeldt, 2015). Since 2005, Åkesson has remained party leader. In the 2006 election, the SD significantly increased its support in the municipality of Sölvesborg, more than doubling their seats in the municipal council and winning almost ten percent of the votes. As party leader Åkesson participated in a number of debates and hearings on both television and radio (jimmieåkesson.se).

On October 19, 2009, Aftonbladet published a debate article by Åkesson that was critical of Islam. The article argued that various phenomena associated with Islam were the "greatest foreign threat to Sweden since World War II." The article highlighted Muslims as Sweden's biggest foreign threat (Åkesson, 2009). It received massive attention and reaction. Åkesson met Business Minister and Deputy Prime Minister Maud Olofsson in a live debate on SVT (Stensson, 2009). The Center for Racism applied to the Swedish Attorney General (Justitiekanslern - JK) about the article potentially inciting violence against various ethnic groups (Aftonbladet, 2009). JK did not, however, consider that the article's content constituted incitement against an ethnic group and decided not to initiate an investigation about it (Justitiekanslern, 2009).Despite reactions from political and intellectual circles, an opinion poll conducted by United Minds Opinion Institute and Synovate in October 2009 found that the debate had increased support for the SD (Brors, 2009). In February 2010, the DSM magazine released a survey showing that according to 150 leading Swedish writers, debate editors, chroniclers, and social debaters, Åkesson was Sweden's 9th most crucial opinion leader (Brors, 2010).

In the 2010 general election, the SD passed the 4 percent national election threshold for the first time and entered the Riksdag with 5.70 percent of all votes, gaining 20 seats (Nyberg, 2010). Åkesson was elected together with 19 of his fellow party members. In 2013, Åkesson published his autobiography Satis Polito (Åkesson, 2013). Fokus magazine ranked Åkesson as Sweden's 5th most powerful person of the year (Fokus, 2013). 
In September 2014, Sveriges Radio's (SR) Ekot reported that Åkesson spent about 500,000 Swedish kron $(\$ 70,000)$ on online betting in 2014 alone. The sum is more than a politician could earn in a year after tax (The Local, 2014). The revelation caused an uproar, both among people who view Åkesson as unreliable and those who opposed SR's decision to publish the information. Åkesson called SR's actions an attempt at "character assassination" (Eriksson \& Olsson, 2014). Following the 2014 election, Åkesson announced he would be on sick leave due to burnout, during which Mattias Karlsson became temporary party leader (Holender et al, 2014). In early 2015, Åkesson was named as Sweden's most important opinion leader of 2014 by DSM; the authors of the piece claimed that he had changed the political landscape (DSM, 2015) of the county. In an interview with Fredrik Skavlan on March 23, 2015, Akesson announced his gradual return to Swedish politics (Lisinski, 2015). 


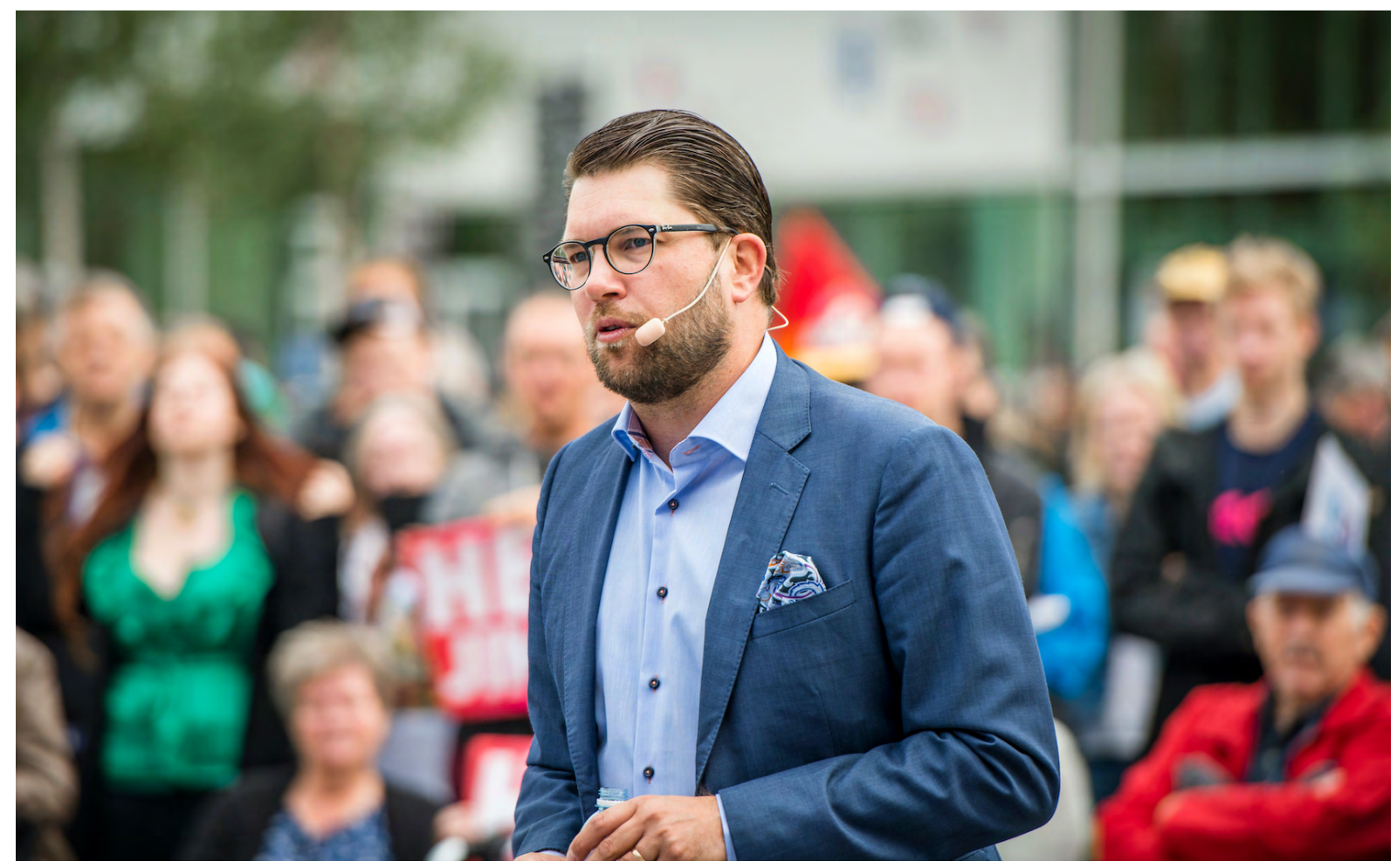

Sweden Democrats' Square Meeting in Umeå. Jimmie Åkesson speaks to the people on the city square where opposition left-wingers have formed a chain and protest in Umeå, Sweden on August 14, 2018.

\section{A Strong Leader Without Much Charisma}

While several authors consider that charismatic leadership is an essential feature of populism, quite a few others remain skeptical (Pappas, 2016). For Albertazzi and McDonnell, for instance, "the charismatic bond between leader and his followers is absolutely central to populist parties" (Albertazzi \& McDonnell, 2008). Meanwhile, Mény and Surel assert that populism "advocates the power of the people yet relies on seduction by a charismatic leader" (Mény \& Surel, 2002). Weyland also places charisma at the center of his definition of populism, which he sees as "a political strategy through which a personalistic leader seeks or exercises government power" (Weyland, 1999). In a similar vein, lack of charismatic leadership has been proposed as explaining why some populist parties are unable to gain ground in some countries (Smith, 2010), while others have shown empirically that political charisma is an important pre- dictor of the relative success of populist radical right-wing parties (Lubbers et al, 2002 \& Pappas, 2016).

Moreover, organizationally, PRR parties are seen as centralized, with grass-roots members enjoying little influence (Bolin \& Aylott, 2019b). In this context, internal leadership essentially refers to the party organization. It is sometimes suggested that right-wing populist parties are leader-centric and take decisions in a top-down fashion (Heinisch \& Mazzoleni, 2016).A study finds that PRR parties also display lower levels of intra-party democracy than any other parties on the political spectrum (Bolin et al, 2017). Meanwhile, external leadership refers to the electoral arena. Certainly, leaders do seem to greatly affect parties' electoral support (Mughan, 2015); the importance of a party leader's own personal traits are often emphasized (Bennister et al, 2015). In relation to PRR party leaders, the elusive quality of charisma is often assumed to be crucial (Lubbers et al. 2002). However, in a survey of forty-five populist contemporary European populist leaders, only five were categorized as being charismatic (Pappas, 2016). There were genuine leadership contests in the SD in the early 2000 s. The 
party's first formal leader was Anders Klarström, a former member of an outright neo-Nazi party (Nordiska Rikspartiet), who was elected by the 1989 party congress. He was replaced by Mikael Jansson, formerly a member of the Center Party, at the 1995 congress. Although Jansson made the party somewhat more respectable, many thought the progress was too slow. Moreover, he was widely regarded as being a rather uncharismatic and introverted leader. Jansson was also accused of nepotism (Bolin, 2012 \& Widfeldt, 2015). Internal dissatisfaction with Jansson increasingly came to the fore after the 2002 election. A faction of younger SD politicians (known as the Skåne gang) from the party's stronghold of southern Sweden managed to advance its position by acquiring more seats on the party board after each party congress. While Jansson was formally still leader, his standing was increasingly undermined. The advance of this faction was gradually reflected in the orientation of the selection committee. The new balance of power was openly revealed ahead of the 2005 congress when the selection committee nominated Åkesson as new party leader (Ekman \& Poohl 2010). Jansson fought on, but Åkesson managed rather easily to unseat him, with 91 votes to 50 (Jungar, 2016).

Although A kesson is the longest-serving SD leader (Bolin \& Aylott, 2019b), the SD did not rely on charismatic leadership, at least not to the same extent as many other PRR parties (Bergmann, 2017). Swedish political parties have distinct organization cultures, especially with respect to leadership. Normally, leaders are formally accountable only to the extra-parliamentary organization. This is reflected in the formal titles given to the leaders (Bolin \& Aylott, 2019b). The norm is that parliamentary groups are under the firm command of the party leadership and voting discipline tends to be solid (Jensen, 2000). Research has suggested that the SD is somewhat even more centralized and less internally democratic than other Swedish parties (Jungar, 2016), so it might well be that the election of Åkesson's eventual successor will involve less openness than in other parties (Bolin \& Aylott, 2019b).

Any long-serving party leader has to exercise considerable political skill and a good degree of ruthlessness, and Åkesson has been no exception. He has been successful both at holding onto his leadership position and at keeping the SD aligned to his preferred political strategy (Bolin \& Aylott, 2019b). Thus, the SD's transformation and growth has coincided with Åkesson's tenure. Despite being only 25 when he became party leader, he pulled the SD's ideological stance towards mainstream Swedish politics, rhetoric, and symbols. The SD's popular support began to increase (Loxbo \& Bolin 2016). Some of this could be attributed to Åkesson, but socio-political conditions in the country were changing, too. The financial crisis of 2008 had a sharply negative, albeit fairly short-lived, effect on the Swedish economy. As war, chaos, and violence spread through the Middle East, the applications for asylum by refugees - which had averaged less than 10,000 annually from 199599 - rose to over 25,000 annually from 2000-2010 (Migrationsverket, 2019). Economic and social changes are probably insufficient to explain the rise in support for SD, but they surely played a role (Bolin \& Aylott, 2019b).

Despite his grip on power - he has never faced a serious leadership challenge Åkesson is not regarded as particularly charismatic (Jungar, 2016; Bergmann, 2017 \& Eatwell, 2018). According to a study, Åkesson "does not meet even generous definitions of charisma" and is better "described as low-key" (Widfeldt 2015). However, compared with his predecessors, there is no doubt that Åkesson as SD leader has a far broader electoral appeal. Jansson was instrumental in the SD's professionalization, but Åkesson is generally reckoned to be much more eloquent (Bergmann 2017). While he is "rarely described as an inspirational speaker," and although he is not prominent in social media, he has always been called "an effective media communicator" (Widfeldt 2015) and "media-savvy" (Demker, 2012). Åkesson's low-key expression is said to suggest competence and reliability; only rarely does he sound deliberately provocative or outrageous. He is also a good debater (Widfeldt, 2008 \& Bolin 2012), even when subjected to tough questioning about the SD's extreme, neo-Nazi past, or when accused of racism (Bolin \& Aylott, 2019b). Åkesson generally appears calm and sensible - which is exactly how 
voters should perceive him (Poohl, 2011). Thanks to his cool image, Åkesson could make an attempt to broaden the party's support and stretch out to female voters. While doing so, he made it clear that he most definitely is not a feminist. "I'm not a feminist! I am a Sweden Democrat, social conservative and nationalist. But I believe in equality," he said (The Local, 2014). He has also been labeled a liberal - another term he disavows. "Maybe I'm a little softer in my opinions than Jimmy Windeskog, but I just see it as positive. Being liberal, on the other hand, is very destructive to me and of course it is deeply offensive to get such a title," he said in an interview with the Democrat in 2000. Jimmy Windeskog, who was editor of the party's member magazine SD Bulletin between 2000 and 2003, and party secretary between 2001 and 2003, had accused him of being "liberal." Åkesson further explained that the reason he has been perceived as "soft" is because he is "very conservative in his attitude" (Poohl, 2011).

Poohl (2011) wrote that one of the reasons for Åkesson's reputation as a "liberal" is probably his fierce opposition to the death penalty, which was a hot topic during his first year in the party. $\mathrm{He}$ has explained that during his first party meeting in 1996, he raised his voice in the discussion about the SD's demands for capital punishment. Åkesson's opposition to the death penalty is based on a strong conviction of "the inviolable right to life," which also made him a loud opponent of abortion during his SDU years. As a young man he was a member of pro-life (anti-abortion) movement. According to Bolin and Aylott, a clique of his close allies, most of whom he had met at university, has been central to Åkesson's leadership. By 2015 the positions of secretary-general and chair of the parliamentary group, arguably the two most important roles in the party after that of the leader, were in the hands of Åkesson's closest allies, Mattias Karlsson and Richard Jomshof, respectively. At the same time, other long-standing members of the clique were eased out of leading positions when their behavior and statements had become awkward for SD. Admittedly, this took a long time in the case of Kent Ekeroth. Elected to Parliament in 2010, Ekeroth was soon involved in an ear- ly-hours, racially charged contretemps, although this infamous "iron-bar scandal" only came to light two years later. More violence in 2016 led to his being dropped from the party's lists for the 2018 election. Another example was Björn Söder, an old ally of Åkesson's, who was replaced, against his will, as the SD's secretary-general in 2015, although he remained an MP (Bolin \& Aylott, 2019b).

In general, Åkesson is the least popular Swedish party leader. When respondents in an annual national survey have been asked to score each leader on a scale from -5 to +5 , Åkesson's average score has been significantly lower than others (Andersson \& Oscarsson, 2018). While his scores improved over the years, from -2.7 in 2011 to -1.5 in 2017, his relative unpopularity mirrored the fact that the SD remained by far the most disliked party in Sweden (Ryan \& Reiljan 2018).However, Åkesson's average score has ranged from +2.5 in 2012 to +3.4 in 2015 among the SD's sympathizers. Popular or not, Åkesson has proved to be a very capable party leader. He formulated a clear, long-term political strategy and pursued it with steadiness and ruthlessness. He helped take the SD beyond its extremist origins and established it as one of Sweden's three biggest political parties (Bolin \& Aylott, 2019b).

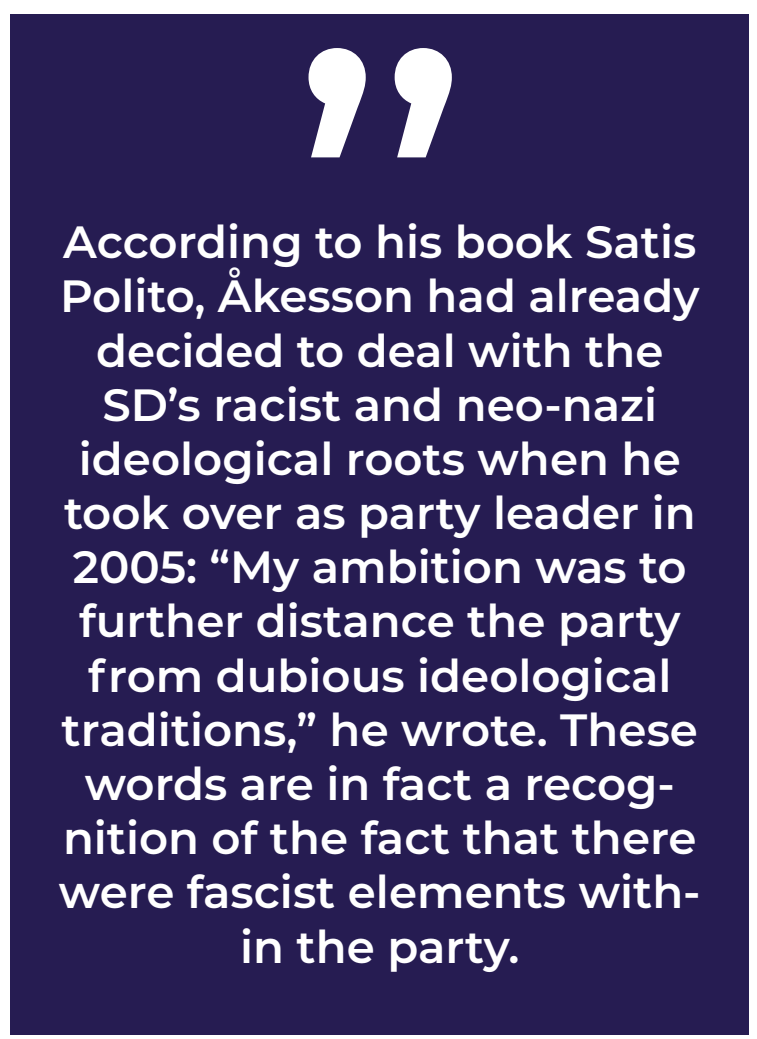




\section{Racism:}

\section{How Successful Has} the SD Been in Changing Its Skin?

According to his book Satis Polito, Jimmie Åkesson had already decided to deal with the SD's racist and neo-nazi ideological roots when he took over as party leader in 2005: "My ambition was to further distance the party from dubious ideological traditions," he wrote. These words are in fact a recognition of the fact that there were fascist elements within the party. Akkesson understood the need for renewal within the party (Åkesson, 2013): just after Åkesson became leader, the party changed its logo from the flaming torch to one featuring an Anemone hepatica, reminiscent of the party's very first, but short-lived logo (Sweden Democrats, 2005). Akesson argued that "the flaming torch accounted for things that happened in and around the party during the lost years of the 1990s."

Other similar fascistic elements were also cleared out. Åkesson said racist slogans such as "Preserve Sweden Swedish" were also replaced with a goal of "making Sweden a little more Swedish." He believed such changes were to "reach new voter groups and thus grow." The party principles adopted in 1999 were free from stakes according to Åkesson and were instead based on "value conservatism" (Åkesson, 2013). Åkesson declared in October 2012 that his party had "zero tolerance" for racism or extremism and urged all "deviants" to leave the party. This happened after several well-publicized cases of gross racism by various representatives.

But critics have claimed that the SD's "zero tolerance" policy is applied to low-level representatives while those higher in the party hierarchy go free (Expo, 2018).

By 2019, well over 100 SD members had been expelled under the zero-tolerance policy. They included several leading members of the SD's youth wing, who were accused by the party leadership of consorting with an extreme right-wing organization. When, in 2015 , an ally of those expelled members was elected chair of the youth wing, the SD leadership simply closed down the wing and replaced it with a new youth organization (Bolin \& Aylott, 2019b). Despite all these changes and purges, critics still wonder whether these measures are sufficient to tame the SD and absolve it of its fascist, racist, neo-Nazi past. Some high-ranking members still use racist rhetoric or engage in far-right political activities. For instance, in 2016, SD lawmaker Anna Hagwall was dismissed from the party for antisemitism after proposing a bill to end state subsidies for media outlets that she claimed favored Jewish-owned media groups (The Times of Israel, 2016).

Hagwall's proposed legislation was openly targeting the Bonnier media group, whose controlling family has Jewish roots. The Bonnier group owns 175 companies, including television and radio stations, newspapers, magazines, and book publishers, and operates in 15 countries. "For many years the SD have been working resolutely to end the currents of antisemitism and conspiracy theories in society," Akesson argued in a statement. He addes, "Through her statements, Hagwall prejudiced this work and the party's image. Anna wants legislation in which people are divided by ethnic appearances. We don't support that." Hagwell also sent an e-mail to Aftonbladet trying to justify her position. "It should not be allowed for any family, ethnic group or enterprise to control directly or indirectly more than 5 percent of the media," she insisted (The Times of Israel, 2016).

In October 2018, a senior SD lawmaker Carina Herrstedt called for action against what she labeled the "control of media by any family or ethnic group," again citing Bonnier. Herrstedt was also widely criticized in the media for writing a racist joke in an email that was deemed offensive to gays, blacks, nuns, Roma, and Jews. Moreover, SD's finance spokesman Oscar Sjostedt was heard in a recording jokingly comparing Jews to sheep being killed in German abattoirs. Because of such remarks, the SD has been accused of espousing antisemitic views despite 
counting Jews among its ranks, including several lawmakers (JTA, 2018).

There have been other scandals. The Swedish newspaper Expressen revealed the fact that active and former neo-Nazis were standing as candidates for the SD in the 2018 election, despite the party claiming to have purged itself of any Nazi sympathizers. The SD's deputy parliamentary speaker Bjorn Söder (a member of Skåne gang) said in summer 2018 that he did not believe Jews or people with indigenous Arctic Sami heritage could be Swedish (Martin, 2018). Söder maintained that he never questioned minorities' rights as Swedish citizens but merely stood up for their rights to preserve their distinct ethnic identities. On Facebook, Söder criticized Annie Lööf, the leader of the Center Party, who wrote on Twitter that "My Jewish friends are simply my Swedish friends: As a citizen of Sweden, you are Swedish, even whether you belong to one of our national minorities or not." Söder claimed that Lööf was "undermining" the status of those five minorities by downplaying their distinctive identities. Söder made similar statements in a 2014 interview with Dagens Nyheter, too (JTA, 2018).

Lena Posner Korosi, who was then the president of the Jewish Council in Sweden, expressed that Söder's reasoning was "reminiscent of 1930s Germany." Meanwhile, Paulus Kuoljok, the president of the Sami Parliament Plenary Assembly called Söder's Facebook post "provocative" and designed to win votes. "They have shown their hostile stance for quite some time, so I'm not surprised," he told SVT.

Despite SD officials frequently saying that they had planned to write a white paper on the party's extremist connections, the project has never become a reality. In summer 2018 Åkesson highlighted Nazism in his speech during the political week at Almedalen: "Nazism can never be nationalism. Nazism is an anti-democratic, socialist, racist, imperialist, violent, international ideology, and it lacks justification for its existence in a democratic society" (Baas, 2018a). However, an examination of more than 6,000 Parliamentary candidates (and thousands more local candidates) from all political parties showed a totally different picture. The result showed that numbers of former members of the violent Nazi organization National Socialist Front (NSF) were running under the banner of Åkesson's SD, including prominent Nazis such as Andreas Olofsson, Thomas Jelinek, Tobias Ekberg, Nina Magnom, Stellan Mårtensson, Morgan Scammel, and others (Baas, 2018a). The study was carried out by Expressen, with the support of Expo.

Furthermore, Åkesson's co-worker and Parliamentary candidate Mikael Bystedt has anonymously written hundreds of comments on hate sites such as Avpixlat and Fria tider. Expressen revealed how Bystedt has systematically spread hatred towards Muslims and called Arabs "the scum of the earth." He dismissed them as "lazy parasites that can't bear to lift a finger and just lie on the couch expecting to be served with both one and the other" (Bass, 2018b).When Expressenreported that mosques were burned down in London, Bystedt wrote, "Damn it was well done! Now we hope this spreads to Sweden like a wildfire." Expressen mapped out how Bystedt systematically and anonymously spread hatred, mainly against Muslims, on sites such as Avpixlat and Fria tider, but also the infamous American site Breitbart. Bystedt wrote the comments with an account that is linked to his private e-mail address, which he used when he became a member of the SD in 2013. He also used the same e-mail address in contacts with authorities, such as the Swedish Companies Registration Office and the Swedish Press, Radio and Television Authority. In comment after comment, he attacked Muslims. In 2015, Bystedt suggested on Avpixlat that Sweden should "expel all Muslims." About the same time, he also presented a five-point program to "save Sweden." Two of the points were: "Stop all immigration / immigration of Muslims. Destroy all traces of Islam in our Swedish society, mosques etc." In order that no one should miss his views on Muslims, Bystedt repeated them again and again: "How many times do we have to say it, Muslims should not live in our countries, OUT OF THEM!"

At Breitbart, Bystedt put forward the conspiracy theory that former US President Barack Obama was in fact a Muslim in disguise who pursued jihad: "Now US 
has got rid of Obama, the Muslim conducting stealth jihad!" In a comment on Avpixlat, Bystedt expressed a belief that segregation was a good thing: "Enough for all people to have equal value. It was probably much safer in the United States when it was apartheid. Do you want to make your homeland safe ... easy, out with Africans and Muslims." When Expressen confronted Bystedt, he said he did not "recognize them [the comments]," even though he has systematically written about 500 comments on the hate sites for four years. When Expressen showed that he had written his personal information in his comments, he confirmed them (Bass, 2018b).

Bystedt has worked as a press assistant at the SD's Parliamentary office. He is the Vice Chairman of the party's Täby branch north of Stockholm, and in the 2018 election, he ran for both City Council and the Riksdag (Bass, 2018b).

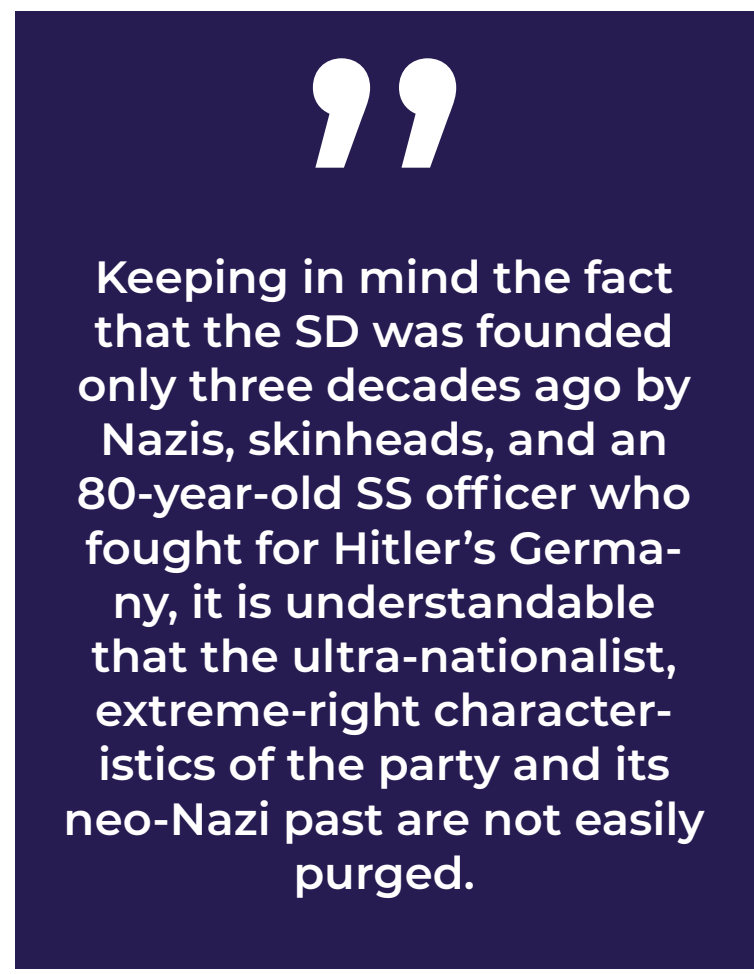

In the 2014 election, Expressen was also able to reveal over ten SD politicians who anonymously wrote racist or otherwise hateful comments on sites such as Avpixlat and Fria tider. One of those revealed was the then-SD official Christoffer Dulny. And in November 2012, the paper revealed how the then-SD politician Erik Almqvist expressed himself in racist and hostile fashion during a night out in Stockholm. Late in the evening, he and his party colleagues Kent Ekeroth and Christian Westling armed themselves with iron pipes (Bass, 2018b).

Keeping in mind the fact that the SD was founded only three decades ago by Nazis, skinheads, and an 80-year-old SS officer who fought for Hitler's Germany (Lindström, 2019), it is understandable that the ultra-nationalist, extreme-right characteristics of the party and its neo-Nazi past are not easily purged. Truly, many party members were involved in the 1990s skinhead wave, either as participants themselves or through friends. Björn Björkqvist, Magnus Söderman, Daniel Friberg, Vávra Suk, Jimmie Åkesson, and Mattias Karlsson all have a background in the skinhead wave (Teitelbaum 2017).

Åkesson confessed in his book that when he was a teenager, he listened to Ultima Thule. Ultima Thule was Sweden's most well-known White Power band. SD circles have claimed that Ultima Thule weren't racist but played a form of extreme nationalist music. The band's first single, which became a success in nationalist circles, was used as a signature melody in the SD's local radio broadcasts (Åkesson, 2013).

According to Lars Lindström, a columnist for Expressen, when Åkesson joined the SD, the political idea of the party was still that "ethnic strangers" should pack and run. Today, the party's program talks about an "inherited essence" that must be preserved and Åkesson himself is concerned that immigrants should be sent back to their countries "where they should live." The SD has always wanted to eject people originating in "distant countries and cultural circles" (party program 2011), including those "outside the Western cultural circle" (1996) from "ethnically distant cultures" (1994) or "overseas origin" (1989). Even today, the SD is working hard to consolidate its intolerance. In the Riksdag, SD proposals have demanded that investment in minorities should end, that minority protections in the Constitution should be removed, and that the Prison and Probation Service should carry statistics on ethnicity going several generations 
back. When the SD has seized power in municipalities, proposals have been put forward with the aim of damaging the Roma and Muslims - "the others" (Lindström, 2019).

PRR parties are commonly referred to as extraordinary or exceptional. Some even study the party category without reference to established mainstream concepts and theories, as if it is "a pathology, and can thus only be explained outside of the 'normal'" (Mudde, 2010). In terms of policy, the parties are often said to have extreme stances on, for example, immigration and nationalism (Bolin \& Aylott, 2019b). "For a couple of decades, many SD politicians in social media have expressed condemnation and malice toward people of different skin color or religion. They are impossible to count: Hundreds of politicians, thousands of posts. So much hatred that you can't get in. It's happening now. Also: MPs from the SD participate in fascist sites, draw antisemitic jokes, call people in town 'blatte-lovers - black lovers' and 'babbe - negro,"' wrote Lindström. (Lindström, 2019).

It is no secret that Åkesson has repeatedly expressed sympathy for Viktor Orban's illiberal regime in Hungary without ever addressing how it is running an antisemitic campaign against the billionaire Jewish philanthropist George Soros. Expo magazine also mapped out nine SD politicians who have retained their mandate despite making rough antisemitic statements. These people were allowed to remain in high ranking positions in the party without being questioned by the SD leadership (Bass, 2018b). And Åkesson saw no problem with hosting Nigel Farage and several ethno-nationalist leaders from eastern Europe at an "alternative Nobel Prize" ceremony in Stockholm (Martin, 2018).

The SD may have neo-Nazi roots, but it is still actively antisemitic - and these traditions have been renewed by the conspiracy theory of how Jewish "cultural Marxism" in the EU leads to mass immigration (Aagård, 2019). A fringe group of neo-Nazi supporters undermine the SD's attempts to clean up its image. In October 2016, even Swedish Prime Minister Stefan Löfven branded the SD as "nazist and rac- ist" (The Times of Israel, 2016).

According to Lindström, in 2018, the SD ran 14 politicians who were members of Nazi organizations or actively spread Nazi or grossly antisemitic propaganda. Whenever journalists have scratched the surface of the party, they have found a politician with ties to a Nazi compound or who wants to shoot refugees on the Öresund Bridge with a shotgun. "Of course, the SD's party leader knows this. He is a political broiler who has served in a racist party since he was a teenager. That's why Jimmie Åkesson has to take a walk when someone highlights the racism in the SD: He knows it's true," Lindström wrote (Lindström, 2019).

"There are still some neo-Nazis in the party," said Anders Sannerstedt, a political scientist at Lund University in southern Sweden. "Akesson said people who in their teens had Nazi links should be forgiven and should be open about it. They still have a lot to do, but they've been more careful this time vetting candidates for election, nationally and locally," he told the BBC in 2018. Sannerstedt said Akesson's drive to broaden the SD's appeal has worked and, like some other rising nationalist parties in Europe, it has a populist agenda setting it apart from the political "establishment" (BBC, 2018). 


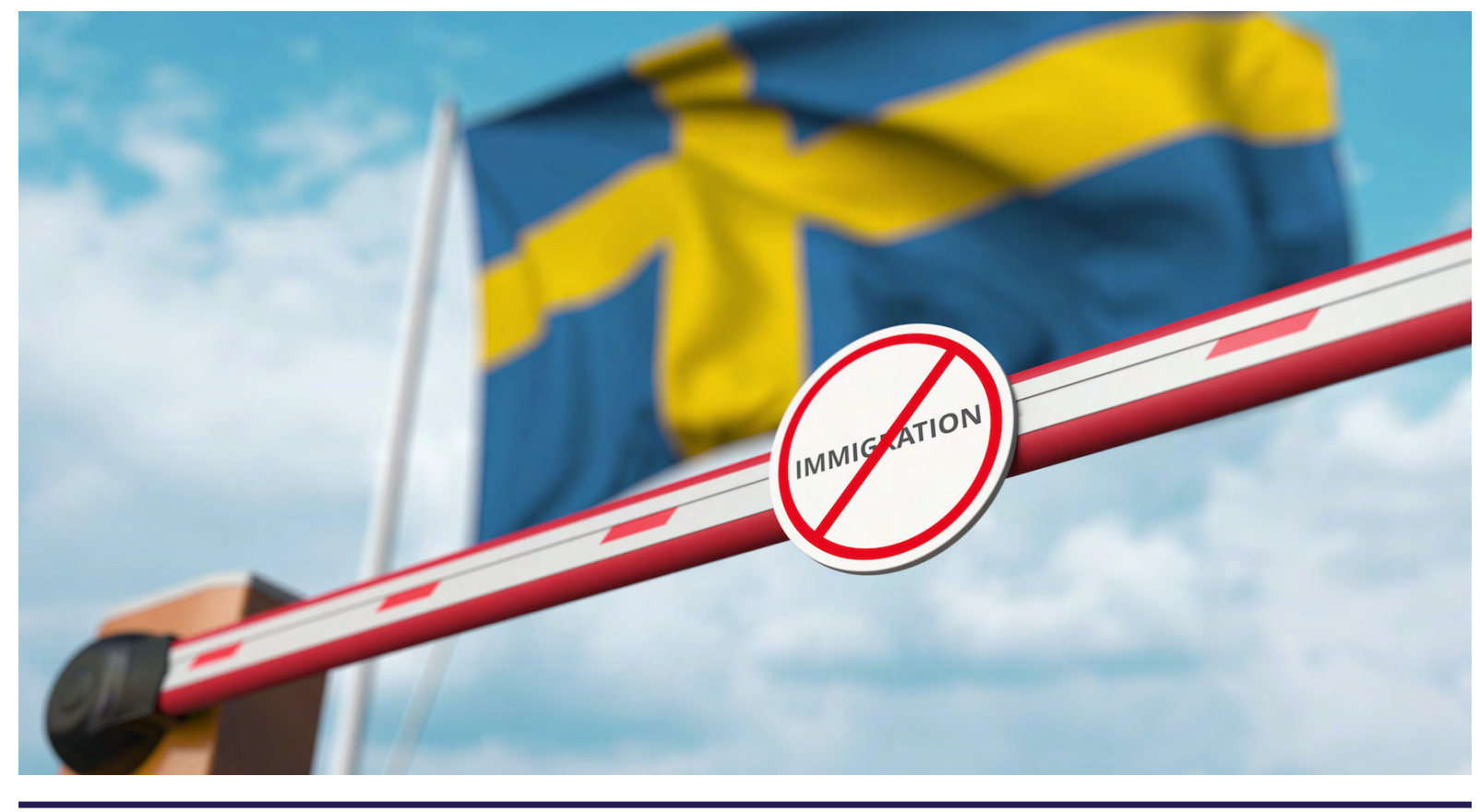

\section{Immigration \&} Multiculturalism:

\section{"Sweden belongs to the Swedes"}

Roger Griffin sees fascism as a form of "populist ultranationalism" that seeks to rebuild the nation after a period of perceived crisis and decline (Griffin, 1993). In his summer 2014 speech, Jimmie Åkesson described the crisis and decline he saw in Sweden: "Mass immigration is an issue of fate," he said. "Mass immigration effects all parts of the society" (Mattsson, 2015). According to Åkesson, mass immigration negatively impacted the welfare, healthcare, and education systems; and "the limit of what is possible to handle has been passed long ago" (SVT Forum, 2014).

Sweden long sought to confirm its status as a "moral superpower" through its previously generous asylum and migration policies, welcoming all those fleeing oppression and war. But the SD has struck a different note. Åkesson argued for "helping refugees locally, in the near vicinity of their home-country," rather than welcoming them to Sweden, warning that allowing them to seek refuge in Sweden would entail too great a burden for the welfare state and may lead to the collapse of Swedish society altogether (Norocel, 2017). This view is not new. In a 2006 interview with Expo, he talked about the years when he applied for the SD. "There were two issues that made me politically interested," he said, meaning immigration and

Sweden long sought to
confirm its status as a "mor-
al superpower" through its
previously generous asylum
and migration policies, wel-
coming all those fleeing op-
pression and war. But Akes-
son argued for "helping
refugees locally, in the near
vicinity of their home-coun-
try," rather than welcoming
them to Sweden, warning
that allowing them to seek
refuge in Sweden may lead
to the collapse of Swedish
society.


the EU. "At the end of the 1980s, a lot of immigrants started to come to our small town. It soon became apparent that it was segregated and that there were contradictions and that it created problems when immigrants arrived in such a short time," said Åkesson; he was ten years old at the end of 1980s (Poohl, 2011).

Åkesson has always opposed multiculturalism and the liberal mixing of cultures that Sweden's mainstream parties have espoused for years. The SD has accused the traditional centrist parties of "wrecking" social welfare by encouraging the arrival of foreigners - especially Muslims - who they argue do not share Swedish values. They try to tie immigrants to crime. As an example, in recent years, shootings have risen in Sweden, something the SD links to the rise in immigration, although official figures show no correlation (BBC, 2018).

According to the SD, multiculturalism poses a threat to the shared values that constitute the cultural community of Sweden. The party defines "Swedish identity" in its programs: "Swedish applies to the one who has a principal Swedish identity and is from her own perspective and by others regarded as Swedish." The rhetorical figure underpinning this message is: Sweden belongs to the Swedes. The idea of a distinct Swedish culture, albeit vaguely defined, is "the glue that binds Swedes together." The projected image is of a long-lost homogeneous Swedish society that clings to the myth of a common ancestry and an original home, to which all "real Swedes" should and could also relate to today (Hellström \& Nilsson, 2010).

As the average annual number of asylum applications has increased since 2011, the SD has tried to exploit this increase by voicing strong skepticism about immigration. Their efforts have, at least electorally, been successful: in 2014, the SD's vote-shared doubled for the fourth-consecutive election, and it became Sweden's third-biggest party. When 163,000 asylum-seekers poured into Sweden in 2015, the SD ramped up its anti-immigration rhetoric (Bolin \& Aylott, 2019b). "Most of the immigrants haven't had a chance to become part of Swedish society and of course many of them have been Muslims and many segregated in suburbs around the big cities, [where they] build parallel societies," said Åkesson. The SD's 2018 election manifesto also said that, "we want to stop receiving asylum seekers in Sweden and instead use real aid for refugees." Åkesson also said that, "we want to enable more immigrants to return to their native countries" (BBC, 2018). In the 2018 election, Åkesson's SD won 17.5 percent of all votes.

Meanwhile, the SD's nostalgic appeal to an idealized and sanitized version of the Swedish welfare system, the folkhem (the people's home) (Hellström et al, 2012), is a style of nativism and welfare chauvinism that has helped the party to increase its influence in Swedish politics. Since the election of Åkesson as chair in 2005 , the party has undergone an ideological transformation in order to normalize populist radical right (PRR) discourse. Thus, references to the Swedish people and their folkhem, their culture, and their Christian (Lutheran) religion replaced former appeals in the SD discourse to safeguarding racial purity, reintroducing the death penalty, banning abortion, and stopping non-European adoptions, albeit arguably in a "racializing manner that often recreates the content of biological racism through different words" (Mulinari \& Neergaard, 2014 \& Norocel, 2017).

Åkesson's speeches consolidate an idealized vision of the folkhem as an exemplary welfare society based on the homogeneous community of Swedish citizens. This line of reasoning was very clearly articulated in Åkesson's speeches from 2011 and 2012, wherein he emphasized that the SD's politics are about "unity and consensus, about a coherent, warm, and solidary Sweden," about a tightly knit society that makes no distinctions "between the privileged or the neglected, there are no sweethearts and no stepchildren ... not one of them despises the other."

In other words, the folkhem envisaged by Åkesson is one built on the ethnic and cultural homogeneity of the Swedish native majority, engaged in an intimate relationship characterized by warmth and solidarity towards one another, in a manner resembling a family united under the folkhem's protective roof. Åkesson makes 
it clear that the SD is driven by a story about the good home for citizens - about the folkhem, a tale of a society where no one is left behind (Norocel, 2017).

By describing the folkhem's inhabitants as family members, Ákesson enforced the idea that the Swedish native majority constitutes a homogeneous community of blood. In so doing, Åkesson specified the criteria for membership in thefolkhem, thereby enforcing a distinction between those "rightfully" belonging to the folkhem's enclosure, and migrant Others as potential intruders among the folkhem's family members. Namely, Åkesson used a discursive distinction between those migrant Others that assimilated into Swedish society and embraced the "Swedish values" underpinning the "Christian, democratic world" that Sweden is part of; and those migrant Others who failed the integration test and instead had willingly joined "the world's Islamists" (Norocel, 2017). In other words, "becoming Swedish" is not a mere matter of fulfilling the administrative citizenship requirements; rather, it entails a more profound process, which hinges on "cultural commensurability with respect to the foundational values that define Europe's cultural heritage" (Betz \& Meret, 2009).

In the seventh chapter of Åkesson's book Satis Polito is entitled "Multiculturalism or Folkhemmet." Åkesson wrote critically of Sweden's immigration policy. According to Ákesson, the ideals were lost "somewhere on the road." He postulated that there is a converse relationship, a dichotomy, between the folkhem and multiculturalism; and immigration threatens national cohesion. Åkesson believes that SD challenges the "political establishment's stance": "We simply do not want the fragmented, segregated, soulless society that the social liberal establishment created for us. We fight against it" (Åkesson, 2013).

The SD asserts that the good "people's home" has been destroyed by "internationalism in the traditional political ideologies [that] have had a full impact on both immigration policy and economic policy. Honorable concepts like the nation and family were trampled on in the dirt."

The SD and Åkesson link crime and moral resolution to "uninhibited immigration.The party program claims: "Sweden is considered to have become a "breeding ground for international leagues, drug syndicates, terrorists and criminals. Murderers and criminals have complete freedom" (Sverigedemokraterna, 1994). In a 1992 issue, the party puplication SD-Kuriren alleged, under the headline "Murdered by immigrants," that 129 Swedes were murdered by immigrants between 1986-1990 and added that, "often these murders have been the results of raw and brutal assaults." The report also claimed that this horrible fact was concealed by the mainstream media and the political establishment (Klarström \& Wikman, 1992).

The campaign for 2018 election concluded with a big row in the final televised debate between the party leaders. Åkesson mentioned the relatively low rates of employment among immigrants and argued that "one must ask the question why it is so difficult for these people to get a job. It is because they are not Swedes. They do not fit in Sweden." Swedish public service television, which hosted the debate, decided that Åkesson's remarks were so "grossly generalizing" that they violated the terms of its mandate (Landahl, 2018). The channel publicly disassociated itself from them. The SD boycotted the broadcaster's remaining election coverage (Aylott \& Bolin 2019).

Tensions were heightened in February 2020, when the Turkish regime announced that migrants were free to cross into Europe. Since 2016, an agreement between Turkey and the EU closed the Turkish/European border to migrants. By reneging on this agreement, Turkey dramatically escalated political tensions throughout Europe, as thousands of migrants and refugees massed on the Greek frontier.

Ákesson travelled to the Greek/Turkish border in March 2020 just to tell the migrants - many of whom have been desperately waiting, camped in the open and hoping to be welcomed by Europe - that his country is full. "So, if you want to go to Sweden, then that is a bad idea. We don't have the capacity to help more," Åkesson told the newspaper Svenska Dagbladet, 
adding that he had traveled to the Turkish border city of Edirne (Daily Sabah, 2020). Åkesson was detained there by Turkish poliçe as he handed out leaflets, and he was escorted to a plane and sent home (Vanttinen, 2020).

Senior Swedish politicians condemned Åkesson's provocative gesture. Swedish migration minister Morgan Johansson led the criticism, telling Swedish news agency TT that the stunt was "totally ridiculous" and that Åkesson only went there to "pose for cameras." Åkesson's party confirmed he had visited Greece, writing on Twitter, "We all remember the migration chaos of 2015 and we have to do everything we can to make sure it never ever happens again." Other Swedish party leaders also criticized the move. Anders Jonsson of the Center Party told TT that it was "not worthy of a Swedish party leader," and Jonas Sjostedt of the Left Party called it "pitiful" in a tweet (Daily Sabah, 2020).

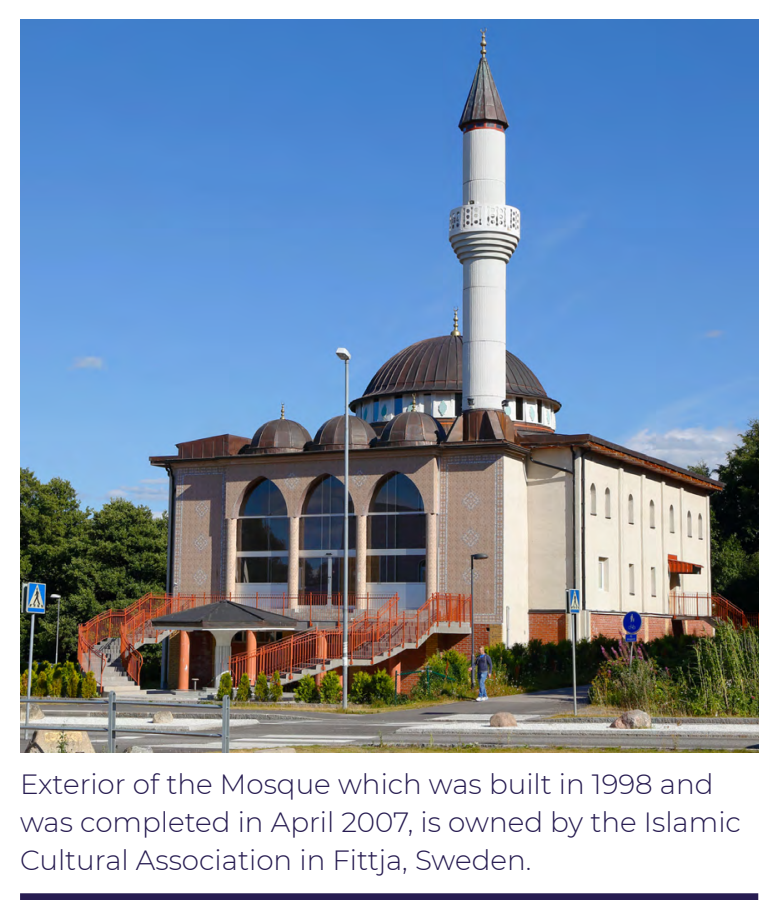

\section{Racism Out,} Islamophobia In

While Åkesson has instituted a much bally-hooed (and selectively enforced) promise of "zero tolerance" for racism within the SD, that promise also foreshadowed a shift in the SD's tactics. The SD condemns neo-Nazi contacts but sees Islamophobia and xenophobia as acceptable. Islamophobia is prevalent among Swedish Democrats, and it is an essential part of the party's core ideology. If Swedish Democrats make Islamophobic statements, they won't be kicked out of the party (Engkvist, 2013).

Åkesson believes that there is a clash of civilizations between Christianity and Islam. Åkesson has underlined that Christianity and its moral values are central cornerstones of the folkhem. This may indicate a thinly veiled assumption that Muslim faith in itself - described by Åkesson as a deeply patriarchal religion of "genital mutilation of completely healthy children" and of "violence and oppression in the name of honor" - constitutes a hindrance for the migrant Muslim Other in their efforts to become a full-edged and law-abiding citizen of the folkhem, which "had been built on democracy and a thousand-year-old Christian foundation" (Norocel, 2017).

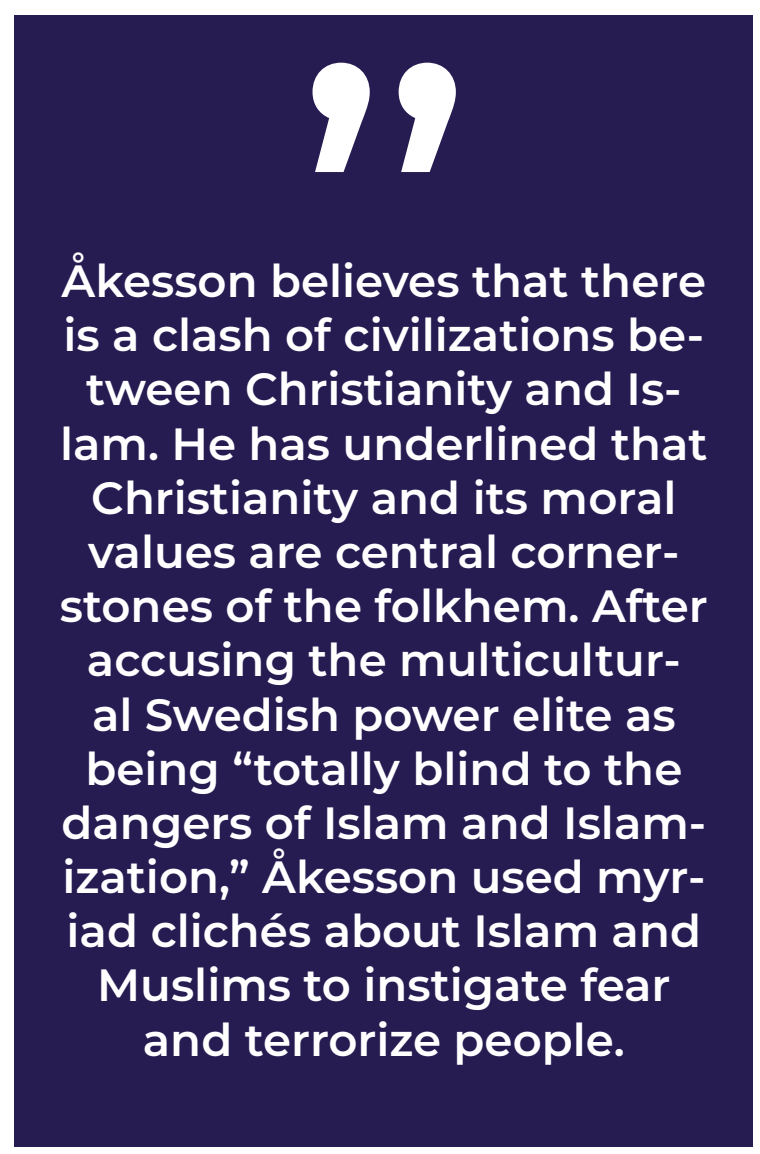


Debatt

\section{Åkesson: Muslimerna är vårt största utländska hot}

\author{
PU⿴囗十⺝ \\ Detta är en debattartikel. Det är skribenten som stär för ảsikterna som förs fram i \\ texten, inte Aftonbladet. \\ DEBATT
}

In an October 2009 opinion piece in Aftonbladet, he argued that the immigration of Muslims has led to Islam adversely affecting Swedish society and that he sees Muslim immigration "as our greatest foreign threat since WWII" (Expo, 2018). According to Åkesson, despite its universal claim, multiculturalism is a monocultural phenomenon that has only found root in the postmodern, oikophobic western world (an oikofob is a person who despises his homeland) (Åkesson, 2009). Åkesson's article in Aftonbladet portrayed his views on Islam as a religion as well as his thoughts on Sweden's Muslim minority; he also expressed what he would do if he came to power. The article contained many of the classic PRR characteristics such as Islamophobia, nativism, racism, fear mongering, etc.

After accusing the multicultural Swedish power elite as being "totally blind to the dangers of Islam and Islamization," Åkesson argued that "Islam differs from Christianity on several crucial points, such as the distinction between spiritual and worldly power and the view of the use of force. Islam has no equivalent to the New Testament and no universal love message. These differences have also made Islam and the Muslim world actively reject the enlightenment and humanism." By highlighting the alleged presence of 1,400 years of war and contradictions between Islam and Christian Europe, Åkesson came to the conclusion that "Islam has affected Swedish society to a much greater extent than Swedish society has affected Islam. Mass immigration from Muslim countries together with the relatively high birth rates within the Muslim population indicates that this development will continue unless a change in political course occurs" (Åkesson, 2009).
Åkesson used myriad clichés about Islam and Muslims to instigate fear and terrorize people by saying, "I think, twenty years ago, most Swedes would find it very difficult to imagine that Islam would become Sweden's second largest religion, that Swedish artists who criticize or joke about Islam would live under constant death threats, that about ten Muslim terrorist organizations would come to establish itself in Sweden, ... that the freezer counters in our grocery stores would offer halal slaughtered meat, while Swedish preschools stop serving meat. Swedish schools would introduce new holidays to celebrate the end of Ramadan while banning more and more church schools and so on" (Åkesson, 2009).

Gender equality is always a difficult issue for culturally racist parties in the Nordic countries in general, and for the SD in particular (Berggren, 2007; Gullestad, 2002 \& Norocel, 2010). On one hand, the party's ideological core is suspicious of gender equality and its connection with feminism; on the other, gender equality constructed as a Swedish national trait is often seen as a fundamental boundary between "us and them." Swedishness, in this context, is gender equality as a national characteristic (Mulinari et al, 2014), as highlighted in an opinion piece by Åkesson: “... that leading representatives of the Muslim community will demand the implementation of Sharia law (Sharialagar) in Sweden; that the Swedish municipal health board (Landsting) would use taxes to circumcise (skära av förhuden) totally healthy young boys; that Sweden would have a higher level of rape and that Muslim men would be strongly represented among the rapists (förövare); that Swedish swimming clubs would introduce separate timetables for women and men, that Swedish municipalities would discuss the possibility of gender-segregated swimming education in schools" (Åkesson, 2009).

He continued: "All of these are parts of Swedish reality today. The question is what it will look like in a few more decades, when the Muslim population, if the current rate holds, has multiplied in size and many of Europe's major cities, including Malmö, are most likely to have a Muslim majority. The multicultural elite 
may see this future as a colorful and interesting change in Sweden and Europe... As a Swedish Democrat, I see this as our biggest foreign threat since the Second World War, and I promise to do everything in my power to reverse the trend when we go to elections next year" (Åkesson, 2009). According to Pew estimates, the number of Muslims in Sweden in 2050 will be approximately 1,130,000 (or 11.1 percent of the population) under a zero-migration scenario; 2,470,000 (or 20.5 percent of the population) under a medium-migration scenario; and 4,450,000 (or 30.6 percent of the population) under a high-migration scenario (Pew Research Center, 2017). As SVT's senior political commentator Mats Knutsson wrote, Åkesson has a "Trump spirit."

Not all media members take a completely hostile attitude to Åkesson. SVT's Bengt Westerberg wrote that Åkesson and other critics of Islam are not wrong in all respects. According to Westerberg, Åkesson and the SD's politicians highlight views and phenomena that do exist and which deserve criticism. But these views are not representative of Muslims in general. Just as there are many expressions of Christianity, there are many of Islam. Moreover, many immigrants from Muslim countries are not practicing Muslims (Westerberg, 2016). A report from the Swedish Agency for Support to Faith Communities in 2017 showed that just 170,915 of Muslims (less than 20 percent) in Sweden regularly practice their religion (Statistik, 2017).

Furthermore, many Muslims leave their home countries in protest of how Islam is practiced there. "Muslims who immigrated to Sweden are also affected by Swedish values. Birth rates are generally not very high in Muslim countries and among Muslims in Sweden. For instance, it is lower in Iran than in Sweden," wrote Westerberg. He added that, "Of course, there is every reason to worry about the radicalization taking place among some young Muslims. But it must primarily be solved through a more ambitious integration policy where the young immigrants get real opportunities for education and work" (Westerberg, 2016). Åkesson's views on Islam and Muslims - as explicated in his controversial article in Aftonbladet - have caused strong reactions, and legal experts say that his views (and those of the SD) vorder on persecution against an ethnic/religious group. For example, Per Hultengård, lawyer for the Swedish Newspaper Publishers' Association, told Aftonbladet that the article could be read as a warning to Swedish Muslims, not in the least due to Ákesson's promise at the end. "I would take that as a threat," said Hultengård (Radio Sweden, 2009).

According to Jan Hjärpe, Professor of Islamic Studies at the University of Lund, the rhetoric used by Åkesson has clear racist undertones, as it is based on the assumption that religion is decisive for how people act: "This is the same kind of propaganda that was used by Nazi antisemites." Hjärpe's views have been shared by the head of the Swedish Muslim Council, Mostafa Kharraki: "This can't be interpreted as anything but racism." At an informal press conference at the Gothenburg University, then-Swedish Prime Minister Fredrik Reinfeldt also said that Åkesson's article reflected what the SD wants to achieve: "This is the core of this party's ideas. They may have spent a whole weekend trying to make it look as if they have several different areas of interest. They don't. They have one area of interest and that is to create an 'us-and-them' scenario" (Radio Sweden, 2009).

Aftonbladet's editor Jan Helin, who decided to print Åkesson's article against the advice of the newspaper's legal experts, would have been legally responsible for the publication and would have been prosecuted for the offense. "I have decided to take that risk. Åkesson's text is important because it shows clearly on what values a party, on its way into Parliament, rests on. You may think that his views are right or wrong. But through reading this article you get a chance to consider what the SD actually believes," Helin wrote, also in Aftonbladet (Helin, 2009 \& Radio Sweden, 2009). 


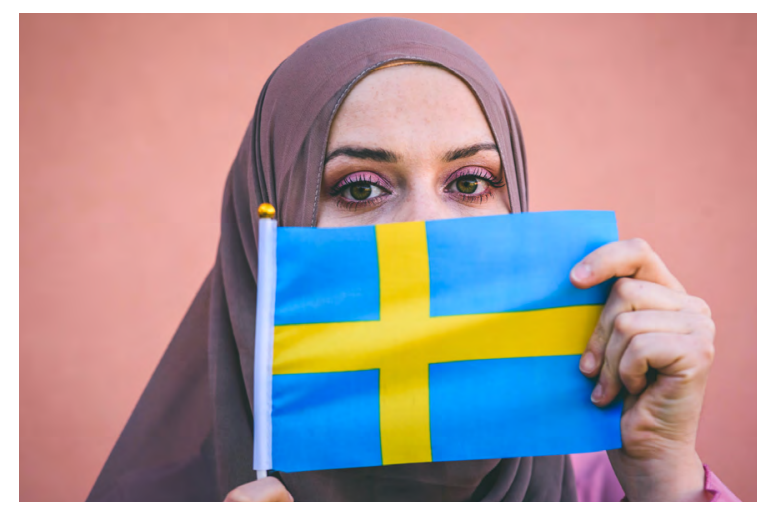

Exterior of the Mosque which was built in 1998 and was completed in April 2007, is owned by the Islamic Cultural Association in Fittja, Sweden.

During an interview with Dagens Nyheter's Jenny Stiernstedt in 2011, Åkesson also stated that extremist Islamism is the biggest factor behind threat of terrorism in Europe and Sweden. He underlined his desire to change Sweden's "extreme" immigration policy without being afraid of being called xenophobic or Islamophobic. He said it is his and his party's right to discuss the dangers and threats facing Sweden. Stiernstedt asked, "Today, many tend to confuse Islamist extremism and Islam. Don't you see a problem with that?" Åkesson's answer showed that he makes no distinction between Islam and extremism: "First, I do not think that there is any particular extremist Islamism. All Islamism is by definition extremist... You cannot disconnect Islamism from Islam, because Islam is not only a religion but also a political ideology that governs every detail of a Muslim's life" (Stiernstedt, 2011).

Åkesson's interview confirmed that there is an Islamophobic way of thinking present in the SD's jargon. If the SD thinks all Muslims are extremists, then increased Muslim immigration only brings Islam's unwanted values. In reality, Islamists constitute a marginal group among Muslims, and extremist Islamism should not be confused with Islam. Radical terrorist groups constitute a very small group among Muslims (Engkvist, 2013). Thus, Åkesson's mix of Islamism and Islam is baseless. When Åkesson speaks of extremist Islam, he suggests non-Muslims should fear an entire faith, despite many practicing Western Muslims endorsing a modernist interpretation of Islam (Gardel, 2010).
In an interview in Sydsvenskan on April 21, 2007, Åkesson also talked about ethnicity and stated that, "it primarily includes culture, language, and religion, but you cannot ignore the fact that appearance also has a certain significance." He also argued that, "whoever says he is primarily a Muslim and secondly Swedish, he is not truly Swedish. I mean that Swedishness cannot be such a public identity that anyone can become Swedish. As I can't become Alban, nor Aboriginal or Chinese either" (Expo, 2018). He even referred to world-famous Bosnian-Swedish football star Zlatan Ibrahimovic as a "mercenary soldier" on the Swedish national soccer team (Hellström \& Nilsson, 2010). Åkesson has also argued that the minaret, a tangible symbol for the "new" multicultural Sweden, generates a feeling of insecurity among the Swedish people (Hellström \& Nilsson, 2010).

In his traditional summer speech in 2014, Åkesson again focused on Islam, immigration, and crime issues. Following a sweeping review of the current global conflict zones, Åkesson shifted his focus to Islam. "In the wake of recent years' developments in Libya, Iraq, Syria and several other countries, I argue that the problem of Islam's bloody borders cannot be denied... Islamism is the Nazism and communism of our time and must be met with the same disgust and with a much stronger resistance than is the case today." This allegation prompted the most generous applause. Åkesson went on to say that Islamism is the greatest global threat to peace, security, democracy, equality, and human rights (Jakobson, 2014).Furthermore, he directed his ire to the handful of Swedish citizens reported to be fighting in Iraq and Syria: "You guys can stay there. Sweden is no longer your home. This country is built on Christian principles" (The Local, 2014).

Åkesson has repeatedly used debates over classism and gender equality to justify his party's opposition to "the unreasonable financial burden" entailed by the Muslim Others' presence within the folkhem. In his speeches, Åkesson reiterated his concerns about Swedish working-class women. Åkesson has stated that the SD's self-appointed task is not only to defend Swedish women from "the menacing 
(male) Muslim Other," but also to prevent them from pursuing emancipatory ac-

tivism on their own, thereby confirming tacitly the patriarchal assumption about male superiority he tries to embody (Norocel, 2017).

As was mentioned above, Åkesson's preoccupation with gender equality as part of the folkhem system is only instrumental and serves a welfare chauvinist purpose to instigate and consolidate the Swedish native ethnic majority's opposition to the presence of the migrant Muslim Other in the folkhem (Norocel, 2010). In Åkesson's imagination, the Swedish Muslim population is a threat to Swedish gender equality: Swedish culture is secular, women-friendly, and respects individuality. In contrary, Muslims are religious, patriarchal, and live in collectivistic cultures (Gardell, 2010; Gullestad, 2002; Razack, 2004 \& Yegenoglu, 1998). This reflects similar developments across Europe, whereby PRR parties' leaders have morphed from "radical right-wing 'thugs' into well-educated and well-dressed demagogues, typifying overtly caring and responsible politicians" (Wodak, 2015).

According to Mulinari et al, the SD justifies through the shared assumption within Swedish public discourse that it is those who belong to the nation that have the power and the right to decide Swedishness. What is specific to Åkesson's SD is that they focus on their right to exclude the other (Mulinari et al, 2014). A key component of these arguments is the connection of the boundary between "us" and "them" to processes of polarization, in which the other is not only different but problematically different; they differ from what is considered normal (Hage, 1998). Islam and Muslims represent the other or outsider in the SD's exclusionist PRR worldview. 


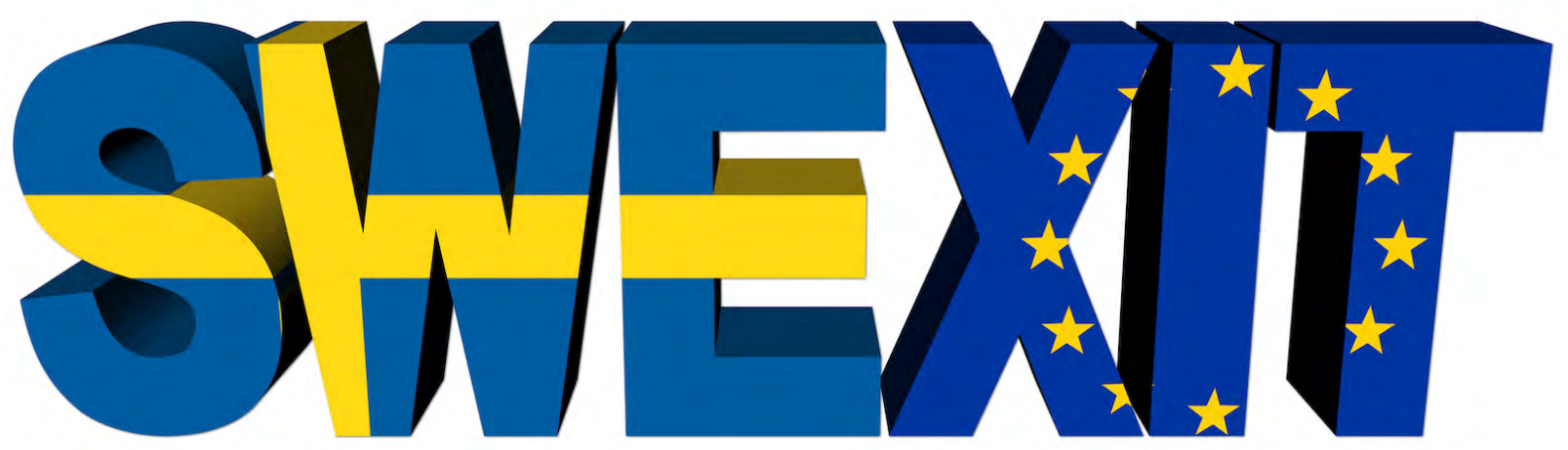

\section{A Sharp U-turn of Euroscepticism}

Continental Europe's PRR parties have always had a complicated relationship with the EU. Unlike the British Eurosceptics, most of them have never been opposed to European integration per se, but rather to the shape it has taken. "Neoliberal," "distant," and "cosmopolitan," Brussels became a perfect strawman in their "fight" against political elites. But this wasn't always the case. In the 1980s, the Front National, like Italian neo-fascists, was a fervent defender of European integration - they saw it as a way to defeat the true enemy, the Soviets. With the end of the Cold War and the signature of the Maastricht Treaty in 1992, all these parties executed a 180-degree turn - from pro-European to Eurosceptics. PRR parties suddenly began fighting for the primacy of the nation-state. Now, opposing the "Eurocrats" and their puppets in the national political mainstream has become the general attitude of PRR parties (Fernández, 2019).

Brexit was a great opportunity for PRR parties - at least, it was in the beginning. With her desire to move away from traditional far-right discourse to a more "transversal" populism, Marine Le Pen championed using Article 50 as the cure to France's problems, many of which stemmed from the EU, she alleged. Invoking Article 50 of the Treaty on European Union (TEU) starts the member state's withdrawal from the EU. In compliance with the TEU, in March 2017 the UK gave formal notice to the European Council of its intention to withdraw from the EU, al-

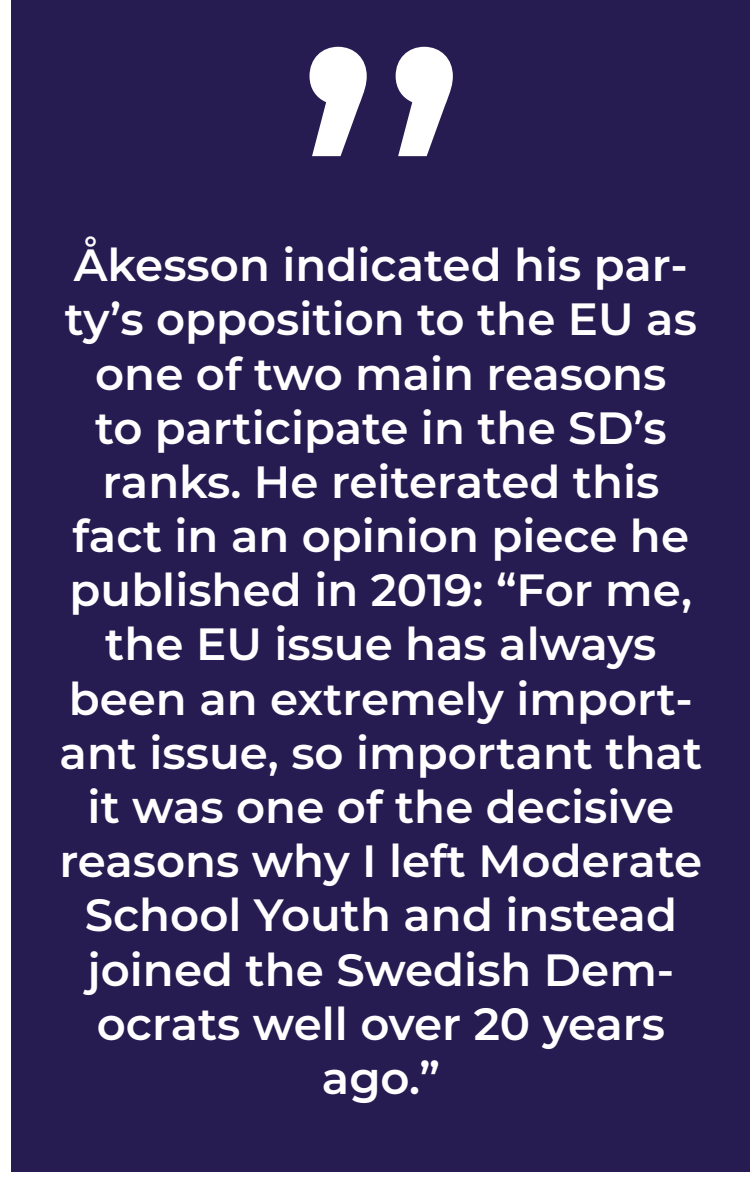

lowing withdrawal negotiations to begin.

Brussels-imposed austerity and the negative perception of how the EU handled the Eurocrisis and the migration crisis fueled anti-EU sentiment across the continent. Along with Brexit, this was an opportunity for right-wing populists to find more suitable and exploitable ground for demanding sovereignty from Brussels (Fernández, 2019).

In his interview with Expo in 2006, Åkesson indicated his party's opposition to the EU as one of two main reasons to participate in the SD's ranks (Poohl, 2011). 
He reiterated this fact in an opinion piece he published in Aftonbladet on Januarry 31, 2019: "For me, the EU issue has always been an extremely important issue, so important that it was one of the decisive reasons why I left Moderate School Youth and instead joined the Swedish Democrats well over 20 years ago" (Åkesson, 2019).

Like many populist radical right parties in Europe, the SD has always been highly Eurosceptic, with Åkesson frequently arguing that the country should hold a referendum on whether it should remain in or leave the EU. Like Britan, Sweden was somewhat peripheral to the EU. If Brexit could happen, why not Swexit?

Åkesson told Reuters in 2014 that his party's sympathizers have relatively little interest in EU politics. "It is obvious that our voters are very reluctant to vote in European elections. We thought maybe it had changed a bit since the last election, but it seems as if our voters are very skeptical about even going and voting." Åkesson and his party argue that national governments should reclaim power from the EU. "For the average SD voter, EU opposition is not why you vote for them, it is because you want another immigration policy," said UIf Bjereld, professor of political science at Gothenburg University (Ahlander, 2014). Åkesson's EU policy called for heavily restricting immigration, opposing Turkey's accession to the EU, and seeking a referendum on EU membership (The New York Times, 2016).

Åkesson has rallied against "bureaucrats in Brussels" for years and as recently as the run-up to the 2018 election gave his full-throated endorsement of a "Swexit" referendum "The EU is not the way to cooperate in Europe," he told channel $\mathrm{Pl}$ of Radio Sweden in August 2018. "My position is that we should renegotiate the terms of our membership and then the people should have their say," he stated. The following month, a SD representative told The Local that, "we want the Swedish people to vote on Sweden's EU membership" (The Local, 2019).

However, the SD has quietly changed its tune on the EU, with party leader Åkesson now saying that the party will be "pragmatic" and try to change the union "from the inside" (The Local, 2019). In January 2019, Åkesson wrote an op-ed in Aftonbladet officially announcing the party's position change away from exiting the EU (Åkesson, 2019). Instead, Åkesson said, the party would now fight for treaty reform. This treaty would undo decades of post-Maastricht integration, but would keep Sweden in the EU (Fernández, 2019). Ákesson has always been against, and says he will always be against, the EU if it continues on a course of supranationalism. "It is the Swedish people who ultimately have to decide how Sweden is governed, not bureaucrats in Brussels or other countries' politicians that we cannot vote for and which we cannot cast aside," he wrote (Åkesson, 2019). "Cooperation is needed to achieve results, and it is through collaboration that opportunities for reforming the $\mathrm{EU}$ from the inside are improved," he stated, adding that the SD would join the European Conservatives and Reformists (ECR) group within the European Parliament and that it had established good relationships with its "Nordic friends in the Danish People's Party and the True Finns" (The Local, 2019).

Although he did not rule out pushing for a "Swexit" referendum "in the long term" if his "vision" of a reformed and less "supranational" EU didn't work out, he said it was simply false that his party is blindly Eurosceptic. "When other parties tried to portray the Sweden Democrats as a protectionist and closed party, it is a false image only intended to distort and smear the Sweden Democrats. We see the benefits, not only the disadvantages, of today's EU cooperation" (Åkesson, 2019) he wrote. Åkesson added that it is important to "be pragmatic and fully utilize the opportunities that exist" within the EU framework (The Local, 2019).

This U-turn led to lots of speculation. Some said the shift must have been Åkesson's, as most PRR parties have have top-down, authoritarian leadership structures. In this sense, the lack of internal democracy was potentially an asset: Without being conditioned by the party base, party leaders can be as pragmatic and as flexible as necessary to pursue whatever political objectives they want (Fernández, 2019). Others evaluated the change of position vis-à-vis the EU as related to wide 
support among the Swedish public for EU membership. Several polls in recent years have suggested that the majority of Swedes are still in favor of EU membership - in fact, support for the EU surged in the wake of Brexit turmoil, as happened in other continental European countries. In an October Eurobarometer poll, a total of 77 percent of Swedish respondents said that EU membership is a good thing, Sweden's highest recorded level since 2007, according to the survey. Among other factors, the British incapacity to deliver Brexit and the negative coverage of Brexit made Europeans more pro-EU (The Local, 2019 \& Fernández, 2019). 


\section{CONCLUSION}

Jimmie Åkesson and his party are not yet authentically democratic - in fact, they're not close. The Sweden Democrats and its leader are still "the same old iron gang as usual" (Ledarredaktion, 2018) despite concerted efforts to change their image. One should always remember that Åkesson himself was in contact with the Swedish Democrats for the first time in 1994, when the party was still marketing itself as overtly racist. Of course, Åkesson has steered the SD away from the Nazi movement onto a more parliamentary path. But its essence - alarmist resistance to immigrants and Islamophobia has remained the same, and there is still no solid indication that Åkesson has matured or moderated over the years. On the contrary, he has emphasized that it was among the Sweden Democrats he found his home (Ledarredaktion, 2018).

Åkesson and his party struggle to be perceived as sincere because they do not want to face their dark past or talk about it. Every time the naked racism of an SD representative has been exposed, the SD claims it's an isolated incident, perpetrated by a rotten egg. But the pattern has repeated again and again; there are too many rotten eggs in the party. Although Åkesson once promised to have a white paper drawn up, he has never delivered on this promise.

Nevertheless, the Christian Democrats (KD) and the Moderates (M) have considered seeking power with the potential support of Åkesson and his party. Of course, Åkesson has more ambitions than supporting others in their success. He primarily wants to push through his politics, and in the long run give the anti-immigrant, racist, Islamophobic, and xenophobic SD as much influence over Sweden as possible. Therefore, Dagens Nyheter's editorial argues "that's why he smiles. He knows that it is not enough to channel people's anger and fear. If the SD is to be the biggest, it must be popular for real. He should approach power step by step. He is a wolf in lamb's wool sweater" (Ledarredaktion, 2018). 


\section{REFERENCES}

— "Jimmie Åkesson - en kort presentation." jimmieakesson.se. http://www.jimmieakesson. se/pres.php (accessed on June 10, 2020).

— (1994). Sverigedemokraternas partiprogram.

- (2005). "Partiets historik i kronologisk ordning." Sweden Democrats. https://web.archive. org/web/20101129031803/ http:/sverigedemokraterna.se/vart-parti/partiets-historik-i-kronologisk-ordning/ (accessed on June 8, 2020).

- (2009). "SD:s debattartikel JK-anmäls." Aftonbladet. Okt.20, 2009. https://www.aftonbladet.se/halsa/a/Rxle45/sds-debattartikel-jk-anmals (accessed on June 10, 2020).

- (2009). "Innehållet i en artikel i Aftonbladet har inte ansetts utgöra hets mot folkgrupp." Justitiekanslern. Okt.23, 2009. https://www.jk.se/beslut-och-yttranden/2009/10/6460-09-31/ (accessed on June 10, 2020).

- (2009). "Sweden Democrats Lash Out Against Islam." Radio Sweden, Okt. 19, 2009. https://sverigesradio.se/sida/artikel.aspx?programid=2054\&artikel=3177386 (accessed on June 9, 2020).

— (2010). "Invalda valet 2010." Parliament of Sweden. https://web.archive.org/ web/20100927180133/ http://www.riksdagen.se/webbnav/index.aspx?nid=1021 (accessed on June 10, 2020).

- (2013). "Sveriges 100 mäktigaste 2013." Fokus. Okt.15. 2014. https://www.fokus.se/2013/11/ sveriges-100-maktigaste-2013/ (accessed on June 10, 2020).

— (2014). "Sweden Democrats head hit by gambling scandal." The Local. Sept.12, 2014. https://www.thelocal.se/20140912/sweden-democrats-in-new-secret-film-scandal (accessed on June 10, 2020).

— (2014). "Åkesson: 'Islamism is the Nazism of our time'." The Local, August 3, 2014. https:// www.thelocal.se/20140803/kesson-islamism-is-the-todays-nazism (accessed on June 9, 2020).

- (2014). Jimmie Åkessons sommartal, (Från 2/8) SVT Forum, Aug.29, 2014.

- (2015) "Sveriges Viktigaste Opinionsbildare 2014 - Jimmie Åkesson: 2014 års Opinionsbildare Nr 1." DSM, Feb. 2, 2015. https://web.archive.org/web/20150202174226/ http://dsm. nu/jimmie2014.pdf (accessed on June 11, 2020).

- (2016). "Far-right Swedish party fires MP over anti-Semitism." The Times of Israel. Dec.5, 2016. https://www.timesofisrael.com/far-right-swedish-party-fires-mp-over-anti-semitism/ (accessed on June 10, 2020).

- (2016). "Europe's Rising Far Right: A Guide to the Most Prominent Parties." The New York Times. Dec.4, 2016. https://www.nytimes.com/interactive/2016/world/europe/europe-far-right-political-parties-listy.html (accessed on June 13, 2020).

- (2017). "Europe's Growing Muslim Population." Pew Research Center. Nov. 29, 2017. https://www.pewforum.org/2017/11/29/europes-growing-muslim-population/ (accessed on June 5, 2020).

- (2017). "Statistik 2017 - Number of people served at registered religious congregations 
which are entitled to government support." Swedish Agency for Support to Faith Communities. https://www.myndighetensst.se/bidrag/organisationsbidrag/bidragsgrundande-statistik/statistik-2017.html (accessed on June 5, 2020).

— (2018). "Jimmie Åkesson." Expo. April 15, 2018. https://expo.se/fakta/wiki/jimmie-akesson (accessed on June 9, 2020).

— (2018). "Sweden Democrats tap into immigration fears." BBC. Sep. 25, 2018. https://www. bbc.com/news/world-europe-29202793 (accessed on June 9, 2020).

- (2018). "Jews are not Swedes, populist right-wing lawmaker says." Jewish Telegraphic Agency (JTA). June 22, 2018. https://www.jta.org/2018/06/22/global/jews-not-swedes-populist-right-wing-lawmaker-says (accessed on June 10, 2020).

- (2019). "Sweden Democrats drop their call for 'Swexit' referendum on leaving EU." The Local, Feb.1, 2019. https://www.thelocal.se/20190201/sweden-democrats-drop-their-call-forswexit-referendum-on-leaving-eu (accessed on June 10, 2020).

— (2019). Asylum statistics. Migrationsverket (Swedish Migration Agency) (migrationsverket.se).

- (2020). "Swedish far-right criticized over Greek border stunt telling refugees 'Sweden is full'." Daily Sabah. March 6, 2020.

Aagård, Martin. (2019). "SD har ett problem med antisemitism." Aftonbladet, Dec.16, 2019. https://www.aftonbladet.se/kultur/a/wPpE95/sd-har-ett-problem-med-antisemitism (accessed on June 10, 2020).

Adolfsson, Viktor. (2013). "Jimmie hade flaggor och så." Nyheter24. Mars 5, 2013. https://nyheter24.se/nyheter/politik/739783-jimmie-hade-flaggor-och-sa (accessed on June 10, 2020).

Ahlander, Johan. (2014). "Anti-immigrant Sweden Democrats struggle to rouse voters for EU polls." Reuters, May 12, 2014. https://www.reuters.com/article/us-eu-election-sweden-idUSBREA4BOPH20140512 (accessed on June 13, 2020).

Åkesson, Jimmie. (1997). "Sagan om SDU Sölvesborg". SDU-Syds medlemsblad.

Åkesson, Jimmie. (2009). "Muslimerna är vårt största utländska hot'." Aftonbladet. Okt.19, 2009. https://www.aftonbladet.se/debatt/a/VRx8zd/akesson-muslimerna-ar-vart-storsta-utlandska-hot (accessed on June 10, 2020).

Åkesson, Jimmie. (2013). Satis Polito. Asp \& Lycke, Sölvesborg.

Åkesson, Jimmie. (2019). "SD: Därför ändrar vi vår EU-politik." Aftonbladet, Jan.31, 2019. https://www.aftonbladet.se/debatt/a/A2Kpyr/sd-darfor-andrar-vi-var-eu-politik (accessed on June 15, 2020).

Albertazzi, Daniele \& McDonnell, Duncan. (2008). Twenty-First Century Populism: The Spectre of Western European Democracy. Basingstoke: Palgrave Macmillan.

Andersson, D. \& H. Oscarsson. (2018). "Kända och populära partiledare." In: U. Andersson, A. Carlander, E. Lindgren and M. Oskarson (eds), Sprickor i fasaden Göteborgs universitet: SOM-institutet.

Aylott, Nicholas \& Bolin, Niklas. (2019a). "A party system in flux: the Swedish parliamentary election of September 2018," West European Politics, http://www.diva-portal.org/smash/ get/diva2:1301277/FULLTEXT01.pdf (accessed June 1, 2020). 
Baas, David. (2018a). "Ex-nazisterna som kandiderar för SD." Expressen. Aug. 28, 2018. https://www.expressen.se/nyheter/ex-nazisterna-som-kandiderar-for-sd// (accessed on June 10, 2020).

Bass, David. (2018b). “SD-politikern: Araber är 'jordens avskum'." Expressen. June 19, 2018. https://www.expressen.se/nyheter/sd-politikern-araber-ar-jordens-avskum/ (accessed on June 10, 2020).

Bergmann, Eirikur. (2017). Nordic Nationalism and Right-Wing Populist Politics: Imperial Relationships and National Sentiments. Palgrave-MacMillan.

Berggren, E. (2007). "Danish xenophobia: Power logic in motion." In: Berggren, E.; Likić-Brbrić, B.; Toksöz, G. \& Trimikliniotis, N. (eds). Irregular Migration, Informal Labour and Community: A Challenge for Europe. Maastricht: Shaker.

Betz, H.G. \& Meret, S. (2009). "Revisiting Lepanto: The political mobilization against Islam in contemporary Western Europe." Patterns of Prejudice, 43, 313-334.

Bolin, N. (2012). Målsättning riksdagen. Ett aktörsperspektiv på nya partiers inträde i det nationella parlamentet. Umeå: Department of Political Science, Umeå University.

Bolin, N., N. Aylott, N., B. von dem Berge and T. Poguntke. (2017). "Patterns of Intra-Party Democracy Around the World." In: S. Scarrow, P. Webb and T. Poguntke (eds), Organizing Representation: Political Parties, Participation, and Power. Oxford: Oxford University Press.

Bolin, Niklas \& Aylott, Nicholas. (2019b). "Right-Wing Populist Party Leadership in Sweden: One of a Kind or one of the Crowd?" Polish Political Science Review. Vol. 7, no 1, p. 24-40.

Brors, Henrik. (2009). "Stödet minskar för de rödgröna." Dagens Nyheter. Okt.28, 2009. https://www.dn.se/arkiv/sverige/stodet-minskar-for-de-rodgrona-3/ (accessed on June 10, 2020).

Brors, Henrik. (2010). "Reinfeldt åter viktigaste opinionsbildaren." Dagens Nyheter. Feb.15, 2010. https://www.dn.se/nyheter/politik/reinfeldt-ater-viktigaste-opinionsbildaren/ (accessed on June 10, 2020).

Byström, Max \& Tuvhag, Emmylou. (2014). "Åkesson ser Islamism som globalt hot." Svenska Dagbladet. Aug.3, 2014.

Demker, M. (2012). "Scandinavian Right-Wing Parties: Diversity More than Convergence?" In: A. Mammone, E. Godin and B. Jenkins (eds). Mapping the Extreme Right in Contemporary Europe: From Local to Transnational. London: Routledge. 239-253.

Duxbury, C. (2014). "Sweden's Anti-Immigration Party Gets Stand-In Leader." The Wall Street Journal. Oct.20, 2014. http://www.wsj.com/articles/swedens-anti-immigration-party-gets-stand-in-leader-1413813180 (accessed on June 10, 2020).

Eatwell, R. (2018). "Charisma and the Radical Right." In: J. Rydgren (ed.) The Oxford Handbook of the Radical Right. Oxford: Oxford University Press. 251-268.

Engkvist, Hanna. (2013). Sverigedemokraterna och islamofobi - En analys av islamofobiska inslag i Sverigedemokraternas politiska uttalanden och av valfilmen från 2010. Human Rights Studies, Lund University. https://lup.lub.lu.se/luur/download?func=downloadFile\&recordOld=4238056\&fileOld=4238086 (accessed on June 9. 2020).

Eriksson, Gustaf \& Olsson, Hanna. (2014). "Åkesson om spelavslöjandet: 'Försök till karaktärsmord'." Aftonbladet.Sept.12, 2014. https://www.aftonbladet.se/nyheter/a/ddGGLw/akesson-om-spelavslojandet-forsok-till-karaktarsmord (accessed on June 10, 2020). 
Fernández, David. (2019). "Should I stay or should I go? Why right-wing populists stopped wanting to leave the EU." Current Affairs. Oct.2, 2019. https://www.thenewfederalist.eu/ should-i-stay-or-should-i-go-why-right-wing-populists-stopped-wanting-to?lang=fr (accessed on June 10, 2020).

Gardell, M. (2010). Islamofobi. Stockholm: Leopard.

Gullestad, M. (2002). "Invisible fences: Egalitarianism, nationalism and racism." The Journal of the Royal Anthropological Institute. 8(1): 45-63.

Griffin, Roger. (1993). The Nature of Fascism. Psychology Press.

Hage, G. (1998). White Nation: Fantasies of White Supremacy in a Multicultural Society. Annandale, NSW: Pluto Press.

Heinisch R. \& O. Mazzoleni (eds.). (2016). Understanding Populist Party Organisation: The Radical Right in Western Europe. Basingstoke: Palgrave Macmillan.

Helin, Jan. (2009). "Åkesson visar sitt sanna jag." Aftonbladet. Okt.19, 2009. https://www. aftonbladet.se/nyheter/a/yvzd6e/akesson-visar-sitt-sanna-jag (accessed on June 15, 2020).

Hellström, Anders, and Tom Nilsson. (2010). "'We Are the Good Guys': Ideological Positioning of the Nationalist Party Sverigedemokraterna in Contemporary Swedish Politics." Ethnicities 10, no. 1 (2010): 55-76.

Hellström, A.; Nilsson, T. \& Stoltz, P. (2012). "Nationalism vs. nationalism: e challenge of the Sweden democrats in the Swedish public debate." Government \& Opposition, 47, 186-205.

Holender, Robert; Carp, Ossi \& Eriksson, Karin (2014). "Åkesson sjukskriven på obestämd tid." Dagens Nyheter. Okt.17, 2014. https://www.dn.se/nyheter/politik/akesson-sjukskriven-pa-obestamd-tid/ (accessed on June 11, 2020).

Jakobsson, Johannes. (2010). Rasism i slips: Sverigedemokrater och nazister idag. LL-förlaget, Stockholm.

Jakobson, Hanna. (2014). "Jimmy Åkesson (SD) kritiserade islamister." Expressen. Aug. 2, 2014. https://www.expressen.se/nyheter/jimmie-akesson-sd-kritiserade-islamister/ (accessed on June 9, 2020).

Jensen, T. K. (2000). "Party Cohesion." In: P. Esaiasson and K. Heidar (eds). (2000), Beyond Westminster and Congress: The Nordic Experience. Ohio State Univ Press. 210-36.

Jungar, A. C. (2016), "The Sweden Democrats." In: R. Heinisch and O. Mazzoleni (eds). Understanding Populist Party Organisation: The Radical Right in Western Europe. London: Palgrave. 189-219.

Klarström, Anders \& Wikman, Gabriel. (1992). "Mördade av invandrare." SD-Kuriren. Nr: 16-17, 1992.

Landahl, Eva. (2018). "Därför markerade SVT mot Åkessons uttalande i slutdebatten." SVT. Sept. 8, 2018. https://www.svt.se/nyheter/svt-s-markering-mot-akessons-uttalande-i-slutdebatten (accessed on June 12, 2020).

Ledarredaktion. (2018). "Jimmie Åkesson är en ulv i lammullströja." Dagens Nyheter. August 24, 2018. https://www.dn.se/ledare/jimmie-akesson-ar-en-ulv-i-lammullstroja/ (accessed on June 15, 2020).

Lindström, Lars. (2010). “Jimmie Åkesson håller så låg profil här." Expressen. Sep.18, 2010. 
https://www.expressen.se/nyheter/val-2010/jimmie-akesson-haller-sa-lag-profil-har/ (accessed on June 10, 2020).

Lindström, Lars. (2019). "Därför måste Jimmie Åkeson ta en promenad när någon belyser rasismen i SD." Expressen.Okt.21, 2019. https://www.expressen.se/kronikorer/lars-lindstrom/ darfor-maste-jimmie-akesson-ta-en-promenad-nar-nagon-belyser-rasismen-i-sd//accessed on June 10, 2020).

Lisinski, Lars Aden. (2015). "Åkesson tillbaka som partiledare för SD." SVT. Mar.23, 2015. https://www.svt.se/nyheter/inrikes/uppgifter-akesson-tillbaka-som-partiledare-for-sd (accessed on June 11, 2020).

Loxbo, K. \& N. Bolin. (2016). "Party Organizational Development and the Electoral Performance of the Radical Right: Exploring the Role of Local Candidates in the Breakthrough Elections of the Sweden Democrats 2002-2014." Journal of Elections, Public Opinion and Parties. 26:2, 170-190.

Lubbers, Marcel; Gijsberts, Mérove \& Peer Scheepers. (2002). "Extreme Right-Wing Voting in Western Europe," European Journal of Political Research. 41.

Martin, Will. (2018). "Sweden is starting to talk about leaving the EU - here's what a 'Swexit' might look like." Insider. Sept.9, 2018. https://www.insider.com/swexit-what-happens-ifsweden-leaves-eu-2018-9 (accessed on June 10, 2020).

Mattsson, Per-Göran. (2015). Fascismens återkomst i nya kläder? En analys av SverigeDemokraternas Idé-traditioner.Master Thesis. Swedish National Defence Collede.

Mény, Yves \& Surel, Yves. (2002). "The Constitutive Ambiguity of Populism." In: Democracies and the Populist Challenge, edited by Yves Mény and Yves Surel. Basingstoke: Palgrave Macmillan, 2002.

Mughan, A. (2015). "Parties, Conditionality and Leader Effects in Parliamentary Elections." Party Politics. 21:1. 28-39.

Spring 2015. http://www.diva-portal.org/smash/get/diva2:817207/FULLTEXT01.pdf (accessed on June 10, 2020).

Mulinari, Diana, Anders Neergaard, Gail Lewis \& Madeleine Kennedy-Macfoy. (2014). "We Are Sweden Democrats Because We Care for Others: Exploring Racisms in the Swedish Extreme Right." European Journal of Women's Studies. 21, no. 1 (2014): 43-56.

Mulinari, Diana \& Neergaard, Anders. (2014). "We are Sweden Democrats because we care for others: Exploring racisms in the Swedish extreme right." European Journal of Women's Studies, 21, 43-56.

Norocel, O. C. (2010). "Constructing radical right populist resistance: Metaphors of heterosexist masculinities and the family question in Sweden." NORMA - Nordic Journal for Masculinity Studies. 5, 169-183.

Norocel, Ov Cristian. (2017). "Åkesson at Almedalen: Intersectional Tensions and Normalization of Populist Radical Right Discourse in Sweden." NORA - Nordic Journal of Feminist and Gender Research, 25, no. 2 (2017): 91-106.

Nyberg, Per. (2010). "Swedish far-right leader: Success due to immigration backlash." CNN. Sept.21. 2010. https://edition.cnn.com/2010/WORLD/europe/09/20/sweden.election/ (accessed on June 10, 2020).

Nyman, Emelie. (2015). "Expo: Skrift ger ny bild av Åkessons förflutna." Svenska Dagbladet. 
Nov.28, 2015. https://www.svd.se/expo-skrift-ger-ny-bild-av-akessons-forflutna (accessed on June 10, 2020).

Pappas, Takis S. (2016). "Are Populist Leaders 'Charismatic'? The Evidence from Europe." Constellations. 23, no. 3 (2016): 378-90.

Poohl, Daniel. (2011). "Jimmies väg till toppen." Expo. Jan.14, 2011. https://expo.se/2011/01/jimmies-väg-till-toppen (accesed on June 9, 2020).

Razack, S. H. (2004). "Imperilled Muslim women, dangerous Muslim men and civilised Europeans: Legal and social responses to forced marriages." Feminist Legal Studies. 12: 129174.

Ryan, A. \& A. Reiljan. (2018). "Åsikts- och känslomässig polarisering 1985-2014." In: D. Karlsson (ed.). Folkets främsta företrädare. Göteborgs universitet. 129-150.

Smith, Jason Matthew. (2010). "Does Crime Pay? Issue Ownership, Political Opportunity, and the Populist Right in Western Europe." Comparative Political Studies. 43: 1490.

Stensson, Carina. (2009). "Hetsigt när Åkesson diskuterade med Olofsson." Svenska Dagbladet. Okt.20, 2009. https://www.svd.se/hetsigt-nar-akesson-diskuterade-med-olofsson (accessed on June 10, 2020).

Stiernstedt, Jenny. (2011) "De flesta terrorister tenderar att vara muslimer." Dagens Nyheter. Jan.26, 2011. https://www.dn.se/nyheter/varlden/de-flesta-terrorister-tenderar-att-vara-muslimer/ (accessed on June 13, 2020).

Teitelbaum, Benjamin. (2018). "Missing Links: Politics and the Misrecognition of the Sweden Democrats." Scandinavian - Canadian Studies. 25 (2018): 50.

Vanttinen, Pekka. (2020). "Leader of Sweden Democrats deported from Turkey." Euractiv. March 9, 2020. https://www.euractiv.com/section/all/short_news/stockholm-leader-of-sweden-democrats-deported-from-turkey/ (accessed on June 15, 2020).

Weyland, Kurt. (1999). "Neoliberal Populism in Latin America and Eastern Europe." Comparative Politics. 31 (1999): 381.

Westerberg, Bengt. (2016). "Vad menade du egentligen, Jimmie Åkesson?" SVT Nyheter, November 17, 2016. https://www.svt.se/opinion/bengt-westerberg-om-sd (accessed on June 9, 2020).

Widfeldt, A. (2015), Extreme Right Parties in Scandinavia, (London: Routledge).

Wodak, R. (2015). The politics of fear: What right-wing populist discourses mean. London: Sage.

Yegenoglu, M. (1998). Colonial Fantasies: Towards a Feminist Reading of Orientalism. Cambridge: Cambridge University Press. 


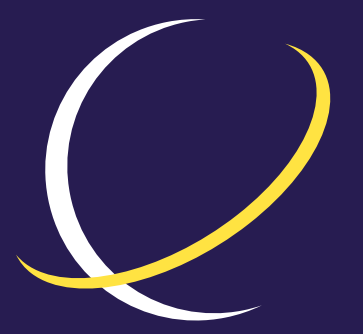

\section{ECPS \\ EUROPEAN CENTER for POPULISM STUDIES}

\section{ABOUT ECPS}

The European Center for Populism Studies (ECPS) is an independent, nonpartisan, nonprofit organization, based in Brussels, for research on and analysis of challenges posed by the resurgence of political populism. ECPS facilitates collaboration among networks of academic experts, practitioners, policymakers, media, and other stakeholders. ECPS offers a platform for the exchange of policy solutions on issues relating to rising populism and provides insights for policy-making and critical analysis to raise broader awareness and engagement through:

\section{Publications}

\section{Academic publications}

Policy reports

White papers

Commentaries

Podcasts and interviews with experts

Events, seminars, workshops, and conferences

\section{Research Programs}

Authoritarianism

Digital Populism

Economics

Environment \& Climate

Extremism \& Radicalisation

\section{Gender}

Human Rights

Foreign Policy

Leadership \& Persona

Migration

\section{ECPS Youth Program}

ECPS Academy 